\title{
Djelatnost Židovske bogoštovne općine u Zagrebu od 1945. do 1946. godine
}

U članku se analizira djelatnost Židovske bogoštovne općine u Zagrebu u razdoblju neposrednog poraća, od ljeta 1945. do 1946., na temelju istražene arhivske građe Općine, koja se čuva u Jevrejskom istorijskom muzeju u Beogradu. Budući da je polovina preživjelih bila pokrštena, prve aktivnosti Općine sastoje se od administrativne pomoći pokrštenima da se vrate na židovstvo, kako bi se i Općina mogla ponovno konstituirati. Općina nastavlja i s brigom za starački dom i njegove preživjele članove, koji su izbjegli deportacije, pruža pomoć preživjelima u obliku smještaja, prehrane i zdravstvene zaštite, traga za udomljenom i skrivenom djecom te pruža pomoć članovima Općine i ostalim hrvatskim Židovima u potrazi za preživjelima te pokretnom i nepokretnom imovinom. Općina do 1946. vodi i matične knjige, katalogizira imovinu u ratu uništenih općina te pokušava ponovno pokrenuti vjerski život.

\section{Uvod}

Već u prvim tjednima svog postojanja, vlasti Nezavisne Države Hrvatske (NDH), usvajajući nacističku politiku prema Židovima, kombinacijom rasnih zakona, antisemitske propagande, konfiskacije imovine, ubijanja Židova kao talaca, počinju progon Židova na svom teritoriju. U Zagrebu su, u trenutku okupacije i proglašenja NDH postojale tri židovske općine: aškenaska neološka u Palmotićevoj 16, s 8.000 članova, Sefardska u Karadžićevoj 3, s 800 članova, te aškenaska Ortodoksna, u Dugoj ulici 32, sa 160 članova. Pokrštenih Židova u Zagrebu tada je bilo 1.245, a Židova stranih državljana, uglavnom izbjeglica iz Reicha, koje je u čekanju vize za dalje okupacija zatekla u Zagrebu, oko $1.800 .{ }^{1}$

Ujutro 11. travnja (dan nakon ulaska njemačkih trupa u Zagreb, 10. travnja 1941.) Gestapo zauzima općinsku zgradu u Palmotićevoj 16, plijeni arhiv, pečati blagajnu i oduzima novac. Ustaške vlasti izbacuju druge židovske institucije iz bloka općinskih zgrada Palmotićeva-Amruševa-Petrinjska: Hevru kadišu (Amruševa 8) i Nadrabinat (Petrinjska 7) te zgrade drugih židovskih institucija. I njihova je

SOBOLEVSKI 1998: 31. 
imovina blokirana i opljačkana. ${ }^{2}$ Tih dana Gestapo i ustaše počinju s pojedinačnim i skupnim uhićenjima, uglavnom uglednih članova židovskih općina na teritoriju NDH. Ustaška policija u nekoliko je navrata, od sredine do kraja travnja, uhitila skupine najimućnijih i najbogatijih članova Općine. Ti su ljudi trebali poslužiti kao zalog za plaćanje kontribucije i pušteni su uz obvezu zajednice da prikupi kontribuciju. Tako je osnovan Odbor za podavanje stvari Židova za potrebe Države, odnosno Kontribucijski odbor, koji je imao zadatak skupiti $1.000 \mathrm{~kg}$ zlata, a svoj je rad započeo 15 . svibnja $1941 .^{3}$

Istoga se dana Općina uselila u prostorije Zaklade Friedfeld, na Tomislavovu trgu 4, s obzirom na to da je Gestapo zauzeo sjedište Općine u Palmotićevoj. Sutradan, 16. svibnja, dopuštena je i obnova rada Općine, prema usmenoj odluci Židovskog odjela Ustaškog redarstvenog povjerenstva u Zagrebu, pod nazivom Židovska bogoštovna općina u Zagrebu. ${ }^{4} \mathrm{U}$ NDH neko vrijeme djeluju i druge općine, od kojih će najduže preživjeti one u Osijeku i Sarajevu (aškenaska i sefardska), koje prestaju s radom tijekom 1942., uslijed deportacije židovskog stanovništva na teritorijima odgovornosti tih općina. ${ }^{5}$

U razdoblju od travnja 1941. do listopada 1942. vlasti Nezavisne Države Hrvatske donose i provode zakonske i druge odredbe, koje su, u prvom redu, bile uperene protiv Židova, a djelomično i protiv drugih etničkih zajednica - Roma

2 GOLDSTEIN 2001: 106-107; SOBOLEVSKI 1998: 28. Autor, za razliku od Goldsteina, navodi: Treći dan nakon njemačke okupacije Zagreba i uspostave NDH, ustaške vlasti zapečatile su prostorije najveće židovske općine u Zagrebu - u Palmotićevoj 16, kao i prostorije njezinih društava i zaklade te blokirale bankovne račune. Hevra kadiša (aramejski חברה קדישא), što znači sveto društvo, jedno je od najstarijih židovskih dobrotvornih društava (njegovi tragovi datiraju se u 4. stoljeće), koje se brine za posljednje potrebe osobe prije smrti, pripremu pokojnika za ukop i sâm ukop, nabavu zemljišta za groblje itd. S vremenom postaje dobrotvorno društvo, koje se brine za bolesnike ili sudjeluje u dobrotvornim akcijama. Makabi je najpopularniji naziv za sportska društva opće cionističke organizacije.

3 TOMAŠEVIĆ 2010: 659, 660, 661; GOLDSTEIN 2001: 162-171. Osim u Zagrebu, ustaške su vlasti provodila uhićenja i u Bjelovaru, Osijeku, Vinkovcima i u nekim drugim gradovima. SOBOLEVSKI 1998: 30-31 navodi da su se uhićenja i organizacija prikupljanja kontribucije događali u dvama valovima - 19. travnja i 8. svibnja. STRČIĆ 1998: 47-58. O slučaju pljačke zlata zagrebačkih Židova postoji niz dokumenata u Fondu Zemaljske komisije za utvrđivanje zločina okupatora i njihovih pomagača u Hrvatskom državnom arhivu u Zagrebu. Židovski odjel imao je zadaću operativnog provođenja protužidovskog zakonodavstva na teritoriju NDH. O kontribuciji u Osijeku pisala je i ŽIVAKOVIĆ KERŽE 2007: 100-101, a u Vinkovcima ŠALIĆ 2002: 432-433.

4 GOLDSTEIN 2001: 234. Odredbom Poglavnika od 3. lipnja 1941. osnovano je Ravnateljstvo ustaškog redarstva za cjelokupno područje NDH, koje je preuzelo poslove Ustaškog redarstvenog povjereništva. Redarstvo je imalo pet odjela: upravno-politički, opći, sigurnosni, židovski i zapovjedništvo ustaških agenata. Ravnateljstvo je djelovalo do rujna 1942., kada njegove poslove preuzima Glavno ravnateljstvo za javni red i sigurnost. Židovski odsjek (HR HDA 252: Ravnateljstvo ustaškog redarstva - Židovski odsjek, opis fonda).

5 ŽIVAKOVIĆ KERŽE 2006: 509-512. 
i Srba. ${ }^{6}$ One se u najvećem broju donose unutar dvaju mjeseca od proglašenja NDH. ${ }^{7}$ Dana 30. travnja objavljene su tri ključne protužidovske zakonske odredbe: Zakonska odredba o rasnoj pripadnosti, Zakonska odredba o zaštiti arijske krvi $i$ časti hrvatskog naroda (njome je naloženo i vraćanje prezimena promijenjenih nakon 1918.) i Zakonska odredba o državljanstvu. Njima su Židovi definirani kao rasa, što je značilo da svoj položaj nikako ne mogu promijeniti. ${ }^{8}$

Dana 4. lipnja 1941. pri Ministarstvu unutarnjih poslova osnovano je Rasnopolitičko povjerenstvo, kojemu je glavni cilj bio utvrđivanje rasne pripadnosti, posebno u sumnjivim slučajevima. U odredbi o osnivanju tog povjerenstva, među drugim glavnim zadacima ističe se djelatnost na izradi ,prijedloga i nacrta zakona, zakonskih odredaba i naredaba, koje zasijecaju u područje rasne biologije, rasne politike i rasne higijene ili eugenike ". ${ }^{9}$ U siječnju 1942., prema Zakonskoj odredbi o nadležnosti za rješavanje židovskog pitanja, ovo je povjerenstvo ukinuto, a nadležnost za Židove prenesena je na Ministarstvo unutarnjih poslova. ${ }^{10}$ Istog dana u lipnju 1941., kada je osnovano Rasnopolitičko povjerenstvo, donesena je i Zakonska odredba o zaštiti narodne i arijske kulture hrvatskog naroda, prema kojoj je Židovima zabranjeno sudjelovanje u radu, organizacijama i ustanovama društvenog, omladinskog, sportskog i kulturnog života hrvatskog naroda uopće,

6 SOBOLEVSKI 1998: 29-31.

7 Popis svih zakonskih odredbi donesenih protiv Židova donosi ZUCKERMAN 2010: 65-67. U ovoj bilješci ne navodim one koji se tiču židovske imovine, s obzirom na to da će se oni obraditi posebno: Zakonska odredba za obranu naroda i države od 17. travnja 1941.; Odredba Ministarstva unutarnjih poslova kojom je Židovima zabranjen polazak kavana, restauracija i gostionica od 21. travnja, a objavljena u tisku 22. travnja 1941.; Zakonska odredba o državljanstvu od 30. travnja 1941.; Zakonska odredba o rasnoj pripadnosti od 30. travnja 1941.; Zakonska odredba o zaštiti arijske krvi i časti Hrvatskog naroda od 30. travnja 1941.; Naredba o zabrani zaposlenja ženskih osoba u nearijskim kućanstvima od 6. svibnja 1941.; Tumačenje o nadopuni zakonske odredbe za obranu naroda i države od 6. svibnja 1941.; Zakonska odredba o nadopuni zakonske odredbe za obranu naroda i države od 8. svibnja 1941.; Naredba o zabrani ritualnog klanja $i$ stavljanja u promet svih vrsti životinja ritualno zaklanih, čije meso služi za ljudsku hranu od 13. svibnja 1941.; Nadopuna naredbe o zabrani uposlenja arijskih osoba u nearijskim kućanstvima od 16. svibnja 1941.; Zakonska odredba o promjeni zakonske odredbe za obranu naroda i države od 23. svibnja 1941.; Zakonska odredba o zaštiti narodne $i$ arijske kulture hrvatskog naroda od 4. lipnja 1941.; Naredba o ustrojstvu i djelokrugu rada Rasnopolitičkog povjerenstva od 4. lipnja 1941.; Naredba o promjeni židovskih prezimena i označavanju Židova i židovskih tvrtka od 4. lipnja 1941.; Naredba o utvrđivanju rasne pripadnosti državnih i samoupravnih službenika i vršitelja slobodnih akademskih zvanja od 4. lipnja 1941.; Izvanredna zakonska odredba i zapovijed od 26. lipnja 1941.

8 Do 1938. istupi iz židovstva bili su vrlo rijetki, no od te godine postaju sve masovniji u nadi da će pokrštavanje pojedincima ili obiteljima donijeti spas. Ustaške su vlasti, međutim, nakon proglašenja rasnih zakona, po uzoru na njemački Reich, Židove definirale kao rasnu kategoriju.

9 NN, br. 43, 4. VI. 1941.; JELIĆ-BUTIĆ: 1977, 179.

10

GOLDSTEIN 2001: 407-408. 
a napose u književnosti, novinarstvu, likovnoj i glazbenoj umjetnosti, urbanizmu, kazalištu i filmu. ${ }^{11}$

Niz se zakonskih uredbi odnosio na židovsku imovinu. ${ }^{12}$ Prva je bila Zakonska odredba o sačuvanju hrvatske imovine, kojom su poništeni svi pravni poslovi između Židova međusobno te Židova i trećih osoba, sklopljeni unutar dvaju mjeseca prije proglašenja NDH, od 18. travnja 1941. Slijedi Odredba o redovitom poslovanju i sprečavanje sabotaže u privrednim poduzećima, kojoj je cilj bio ozakoniti praksu oduzimanja židovskih poduzeća, pod izlikom da se u njima provode sabotaže. ${ }^{13}$ Jedna od ekonomskih odredaba bila je i ona o redovitom poslovanju $i$ sprečavanju sabotaže u privatnim poduzećima, a odnosila se samo na Židove i to one koji su bili vlasnici tih poduzeća, što je uvodilo mogućnost njihova oduzimanja. Vladine agencije preuzele su židovska poduzeća, financijske ustanove i objekte za iznajmljivanje te su ih prodale privatnim strankama ili kasnije nacionalizirale, odnosno podržavile (krajem travnja osnovan je i Ured za obnovu privrede, a samo je on bio ovlašten trgovati poduzećima u vlasništvu Židova ili dijelovima imovine u tim poduzećima). Židovi su masovno otpuštani iz javnih službi i poduzeća, a za određeno su vrijeme zadržani samo oni bez kojih se određena djelatnost nije mogla obavljati. Izuzetak je bio određen broj liječnika. ${ }^{14}$

Prema Tomaševiću, ovo je bila prva faza progona Židova, koja traje od svibnja 1941. do kolovoza 1942. Nju je obilježila diskriminacija i ekskomunikacija. No,

${ }_{11}$ Zakonska odredba o zaštiti narodne i arijske kulture hrvatskog naroda, NN, br. 43, 4. VI. 1941. Vidi i HDA, ZKRZ GUZ, br. 306, kut. 10, 455. i GOLDSTEIN 2001.

12 Popis svih zakonskih odredbi donesenih protiv Židova donosi ZUCKERMAN 2010: 65-67. Prema tom popisu, oni koji se tiču židovske imovine jesu sljedeći: Zakonska odredba o sačuvanju hrvatske narodne imovine od 19. travnja 1941.; Provedbena naredba zakonske odredbe o sačuvanju hrvatske narodne imovine od 19. travnja 1941.; Zakonska odredba o imenovanju povjerenika kod privrednih poduzeća od 19. travnja 1941.; Zakonska odredba o redovitom poslovanju i sprečavanju sabotaže u privrednim poduzećima od 30. travnja 1941.; Zakonska odredba o osnivanju ureda za obnovu privrede od 2. svibnja 1941.; Zakonska odredba o dužnostima i pravima povjerenika, imenovanih kod privrednih poduzeća od 16. svibnja 1941.; Zakonska odredba o dužnostima i pravima povjerenika, imenovanih kod privrednih poduzeća od 16. svibnja 1941.; Provedbena naredba zakonskoj odredbi o ispražnjenju i naseljenju stambenih i poslovnih prostorija iz razloga javne sigurnosti od 5. lipnja 1941.; Zakonska odredba o sprečavanju prikrivanja židovskog imetka od 5. lipnja 1941.; Zakonska odredba o obveznoj prijavi imetka židova i židovskih poduzeća od 5. lipnja 1941.; Zakonska odredba o izvlastbi zgrada u korist države od 9. lipnja 1941.; Zakonska odredba o izvlastbi tiskara od 12. lipnja 1941.; Zakonska odredba o osnutku Državnog ravnateljstva za ponovu od 24. lipnja 1941.; Zakonska odredba o podržavljenju židovske imovine, NN, br. 246, 30. X. 1942. Vidi i KISIĆ KOLANOVIĆ 1998: 429-453.

13 JELIĆ-BUTIĆ 1977: 179; GOLDSTEIN 2001: 118.

14 GOLDSTEIN 2001: 125-131, 223-232; SOBOLEVSKI 1998: 29-30; STRČIĆ 1998: 48. Taj se proces dobro može pratiti u Hrvatskom državnom arhivu u Zagrebu (naročito HR-DAZG-943 - Sudbeni stol u Zagrebu, registri inokosnih, zadružnih i društvenih tvrtki). 
već potkraj svibnja započinje i razdoblje masovnih uhićenja, deportacija u logore i ubijanja, koja će potrajati do kolovoza 1942. Ustaške su vlasti u kontekstu provedbe progona u logore osnovale gotovo trideset sabirnih i prolaznih logora, u koje su privremeno smještale uhićene Židove na putu prema koncentracijskim logorima ili logorima smrti. Među prvima je u travnju osnovan logor Danica kod Koprivnice. $^{15}$

Već se prvih dana lipnja 1941. počinje organizaciono sređivati logorski sustav u NDH. Od polovine lipnja uspostavljen je logorski sustav Gospić - Velebit - otok Pag. Još tijekom svibnja Eugen Dido Kvaternik bio je s ustaško-redarstvenom delegacijom u Trećem Reichu kako bi dobio saznanja i praktične upute o mjerodavnom i operacijskom procesu za provedbu masovnih deportacija i eksterminacija. Logorski sustav Gospić - Velebit - otok Pag bio je planiran i dirigiran iz središnjice Ravnateljstva za javni red i sigurnost (RAVSIGUR) u Zagrebu, a bio je pod neposrednom operativnom nadležnošću Župskog redarstvenog ravnateljstva u Gospiću. Sastojao se od jednoga zatvora, jednoga logora i više improviziranih prihvatilišta i sabirališta u samome Gospiću, od dva logora na otoku Pagu i dva na Velebitu, a glavna poprišta masovnih ubijanja bili su logor Jadovno na Velebitu i logor Slana na otoku Pagu. Tijekom svega dva ljetna mjeseca, od 21. lipnja do 21. kolovoza, u logorskom sustavu Gospić - Velebit - otok Pag nestalo je oko 2500 Židova iz svih dijelova NDH, od toga oko 1000 iz Bosne i Hercegovine. Ti su logori morali polovinom kolovoza biti napušteni, zbog toga što su Talijani, doznavši za zločine i prestrašeni sve jačim ustankom, $s$ vojskom zauzeli taj teritorij. Do kraja srpnja pohapšena je većina Židova u Koprivnici, Karlovcu i Varaždinu. Varaždin je proglašen prvim gradom ,očišćenim “ od Židova. ${ }^{16}$

Ujesen 1941. podignut je novi logorski kompleks na području Jasenovca i Stare Gradiške. Isprva je Jasenovac bio zamišljen kao radni logor po uzoru na nacističke, u kojem su sredstva ubijanja logoraša trebala biti izgladnjivanje i iscrpljivanje Vernichtungsernährung. No, budući da se prema kraju 1941. broj logoraša ubrzano

15 TOMAŠEVIĆ 2010: 661; GOLDSTEIN 2001: 267; SOBOLEVSKI 1998: 29. Potkraj svibnja 1941. uhićeno je 165 omladinaca između 18. i 21. godine, koji su odvedeni pod izlikom da ih se vodi na rad, a odvedeni su u Jadovno i ondje ubijeni. Kako bi opravdao masovno slanje Židova u logore, Ante Pavelić donio je 26. lipnja izvanrednu zakonsku odredbu i zapovijed, u kojoj je kolektivno optužio Židove za širenje glasina i glavne krivce u otežavanju opskrbe stanovništva te im je namijenio mjere zatočenja u sabiralištima pod vedrim nebom: Budući Židovi šire lažne vijesti u svrhu uznemiravanja pučanstva te svojim poznatim spekulativnim načinima smetaju $i$ otešćavaju obskrbu pučanstva, to se kolektivno smatraju za to odgovornim, i prema tome će se proti njima postupati $i$ spremati ih povrh kaznenopravne odgovornosti u zatočenička zbirališta pod vedrim nebom. Dan kasnije Pavelić je bilo kome zabranio dolazak u Poglavnikov ured s ciljem intervencija za Židove, budući da su se pojedinci i skupine građana zalagali za spas pojedinih Židova.

16 GOLDSTEIN 2001: 276-278. 
povećavao, jasenovački su zapovjednici počeli masovno ubijati zatočenike. Jasenovac je ostao u funkciji puna 44 mjeseca, gotovo do samoga kraja rata. Tamo je ubijena većina Židova iz sjeverne Hrvatske i Bosne - njih između 17.000 i 18.000. ${ }^{17}$

Nakon Konferencije u Weinseeu, 20. siječnja 1942., nacisti su počeli s provedbom Konačnog rješenja. Počele su deportacije prema šest logora u okupiranoj Poljskoj: Chełmno, Treblinka, Sobibor, Belzec, Auschwitz-Birkenau, i Majdanek-Lublin, koje su nacisti zvali logori za uništavanje. Ljeto 1942. obilježile su evakuacije geta i deportacije iz brojnih država pod okupacijom ili kontrolom Trećeg Reicha. ${ }^{18}$ U tom se kontekstu Nijemci aktivnije uključuju u deportacije Židova iz Hrvatske na istok. U izvješću Gestapoa iz Zagreba, napisanom u svibnju 1942., tvrdi se da ustaše, unatoč okrutnosti, nisu dovoljno temeljito provele konačno rješenje na teritoriju NDH. Prema tom se izvješću još uvijek oko 5.000 Židova nalazilo na slobodi na teritoriju pod nadzorom ustaških vlasti, zahvaljujući osobnim i obiteljskim vezama, korupciji i zalaganju Katoličke crkve za osobe u miješanim brakovima i njihovu djecu te neke druge osobe. U kolovozu 1942. Nijemci se prvi put u NDH angažiraju u deportacijama Židova iz Hrvatske. Zajedno s ustašama uhićuju oko 5.000 Židova s područja cijele NDH: iz Zagreba i Slavonije te Sarajeva (uključujući logoraše iz Tenje te zatočenice iz Lobora i Gornje Rijeke) i deportiraju ih u Auschwitz vlakovima Državnih željeznica. Policijsku pratnju i sve ostalo u vezi s transportom organizirale su njemačke policijske snage. Troškove su snosile ustaške vlasti. Najviše je Židova bilo iz Sarajeva, čime je taj grad očišćen od Židova. Time, prema Tomaševiću, počinje druga faza uništenja Židova s teritorija NDH.

Drugi val deportacija na istok događa se u travnju i svibnju 1943. na zahtjev Nijemaca i, prema Tomaševiću, označava početak treće faze uništenja Židova u NDH. ${ }^{19}$ Koliko je ova faza bila uspješna vidi se iz dijela posljednjih njemačkih dokumenata, koji se tiču Židova u NDH, datiranih od 13. lipnja 1944., gdje se govori da je u NDH u logorima živo još oko 800 Židova, uglavnom žena i djece (u odnosu na prijeratnih oko 39.000, od čega oko 25.000 u Hrvatskoj i oko 14.000 u Bosni i Hercegovini). ${ }^{20}$

\footnotetext{
Isto: $302-343$.

FRIEDLANDER 2009: 287-345.

GOLDSTEIN 2001: 465-476; TOMAŠEVIĆ 2010: 661-663. Oni su trebali biti deportirani u manjim skupinama (20 - 150 ljudi), u vagonima priključenima na obične vlakove. Plan je bio deportirati oko 2.000 osoba, no deportirano ih je oko 1.200. Himmlerov ured u travnju 1944. od njemačkog poslanstva traži da se još jednom pozabavi tim pitanjem, iako su njemački službenici u Zagrebu smatrali da je židovsko pitanje u NDH riješeno u svibnju 1943. Službenici u Zagrebu odgovorili su da je u Hrvatskoj doista ostao određen broj Židova: počasni arijci, određene osobe u mješovitim brakovima ili polužidovi koji nisu bili u braku sa Židovima, da su ustaške vlasti bile brze i radikalne u provedbi antisemitskih mjera, a provođenje tih mjera dokraja bilo bi problematično jer su mnogi vođe ustaškog režima bili u rodu sa Židovima. 


\section{Djelatnost Židovske bogoštovne općine u Zagrebu u razdoblju Šoa ${ }^{21}$}

Dana 14. svibnja, uz suglasnost Židovskog odjela Ustaškog redarstvenog povjerenstva u Zagrebu, formira se Vijeće Židovske bogoštovne općine u Zagrebu (ŽBOZ). ${ }^{22}$ Općina ponovno počinje raditi 16. svibnja 1941. usmenom suglasnošću Židovskog odjela na novoj lokaciji, na Trgu kralja Tomislava 4 te u iznajmljenim prostorijama u Trenkovoj 9. ŽBOZ više nije niti tradicionalna židovska zajednica (kehila) prije židovskog prosvjetiteljstva (Haskale) i židovske emancipacije, niti tip Gemeinden zajednica u Srednjoj Europi nakon tih procesa, niti modificirana verzija židovske zajednice iz razdoblja zakona iz 1929., već postaje ustanova pod kontrolom ustaških vlasti (Ustaškog redarstvenog povjerenstva, odnosno MUP-a), preko koje se vodila briga za Židove deportirane u logore na teritoriju NDH, kao i za zbrinjavanje i financiranje preostalih Židova u Zagrebu i okolini. Privremeno su, sa sličnim zadacima, postojale i općine u Osijeku te dvije u Sarajevu, ali s imenovanim povjerenicima, do deportacije njihovih članova u logore.

Općina je bila organizirana kroz pet odjela. Imala općinski ured, matični ured, Nadrabinat, Socijalni odsjek (tzv. Skrb za logore ipučku kuhinju) te liječničku ordinaciju i ljekarnu. Otvorila je i vrtić i školu, kao i tzv. obdanište za srednjoškolsku djecu (jer ustaške vlasti nisu odobrile osnivanje srednje škole). Vodila je brigu za starce izbačene iz staračkog doma u Maksimirskoj ulici, nakon okupacije, koji su sada bili smješteni na više iznajmljenih lokacija u Zagrebu i okolici. Rabin Freiberger posjećivao je zatočenike u sabiralištima. Općina je intervenirala kod nadležnih, korespondirala s mnogim pojedincima i

21 Od svog osnutka do 1929. Općina u Zagrebu nazivala se Izraelitskom/Izraelitičkom ili Židovskom bogoštovnom općinom. Od donošenja Zakona o verskoj zajednici Jevreja u Jugoslaviji 1929. (Službene novine Kraljevine Jugoslavije, br. 301/1929) židovske općine nazivaju se jevrejskim vjeroispovijednim općinama (Službeni jezik jevrejskih veroispovednih opština i njihovih centralnih ustanova je službeni državni jezik. Na ovom jeziku vode se i verske matrikule i iz ovih izdaju sva dokumenta. Ovi izvodi imaju karakter javnih isprava, Članak 23. Zakona). Od 1941. Općina mijenja naziv u Židovska bogoštovna općina u Zagrebu, koji će nositi i u neposrednom poraću, iako će se u neposrednom poslijeratnom razdoblju, u svakodnevnoj komunikaciji s ostalim Općinama ili raznim državnim i lokalnim tijelima, paralelno nazivati i Jevrejskom vjeroispovijednom, samo Židovskom, pa čak i Izraelitskom. Nakon što je 1952. iz njezina naziva izbačeno vjeroispovijedna, općina u Zagrebu nosila je do 1991. naziv Jevrejska općina Zagreb, a od 1990-ih Židovska općina Zagreb (ŽOZ). U tekstu koji će obrađivati poratno razdoblje slijedila sam i današnji naziv općine, između ostalog, i zbog imena njezina arhivskog fonda u arhivu JIM-a u Beogradu, ali i naziv Jevrejska vjeroispovijedna općina Zagreb, kao i Jevrejska općina Zagreb, s obzirom na to da se u većini dokumenata i sama naziva tako.

22 GOLDSTEIN 2001: 233-246; SOBOLEVSKI 1998: 31-34. Autor u navedenom članku navodi nekoliko različitih popisa članova Vijeća, kao i svih općinskih tijela te njihovih članova i zaposlenika. 
institucijama u zemlji i u inozemstvu, organizirala nabavu macesa (beskvasnog kruha koji se jede za vrijeme blagdana Pesaha), odašiljanje djece u Mandatnu Palestinu itd. Hram je bio u prostorijama bivše sefardske općine u Karadžićevoj 3, a kasnije u Trenkovoj 9. ${ }^{23}$

Općina je dio svojih aktivnosti tijekom NDH financirala iz doprinosa članova općine, a dio je prikupljala iz prilogâ, koji su stizali od židovskih i ostalih dobrotvornih organizacija i pojedinaca iz Mađarske i Italije te neutralnih zemalja (Portugala, Švicarske i Turske) ili rodbine Židova zatočenih u logorima, koji su izbjegli na teritorij pod talijanskom kontrolom. Općina je molila i ustaške vlasti da deblokiraju račune ŽBOZ-a, što je minimalno učinjeno tek 1942. ${ }^{24}$

Vodstvo općine preuzeo je Hugo Kon (1871. - 1943. $)^{25}$, dugogodišnji prijeratni predsjednik, od 1920. do 1935., i rabin Miroslav Šalom Freiberger (1903. - 1943.). ${ }^{26}$ Nakon deportacija u travnju i svibnju 1943., kada su deportirani svi

23 GOLDSTEIN 2001: 235; SOBOLEVSKI 1998: 28-46. Sredinom svibnja sefardska se općina ujedinila sa ŽBOZ-om; otprilike u isto vrijeme oduzete su joj i prostorije, koje su joj u lipnju vraćene, te se u njima nalazio općinski hram. U rujnu su ustaške vlasti oduzele prostore i ortodoksnoj općini, a njezin je namještaj prebačen u Trenkovu 9. JIM, arhiv ŽOZ, razna mjesta; HDA, fond ZKRZ GUZ, br. 306, kut. 10, 93.

25 GOLDSTEIN: Rukopis Židovskog biografskog leksikona. Pravnik i židovski aktivist. Osnovnu školu i gimnaziju završio u Zagrebu, potom diplomirao i doktorirao na PF-u u Zagrebu. Od 1906. imao odvjetničku kancelariju u Zagrebu. Predsjednik Društva odvjetnika u Hrvatskoj i Slavoniji, član ispitnog povjerenstva za odvjetničke kandidate. Dugogodišnji gradski zastupnik, izabran na izborima za gradsku skupštinu 1921., 1925. i 1927. te u 1930-ima. Aktivan u židovskim društvima, od početka stoljeća cionistički orijentiran. Za predsjednika Židovske općine u Zagrebu izabran 1920. kao cionistički kandidat, što je temeljito promijenilo način funkcioniranja općine. Godine 1935. zahvalio se na dužnosti te postao potpredsjednik Saveza jevrejskih veropispovednih opština Jugoslavije (SJVOJ). Nakon smrti predsjednika JVO-a u Zagrebu, Marka Horna, u svibnju 1941. ponovno preuzima predsjedničko mjesto u Općini. Budući da je poznavao mnoge ustaške dužnosnike još od školskih dana, nastojao je zaustaviti pljačku imovine i izbacivanje iz stanova, potom deportacije, a kasnije je dogovarao pomoć zatočenima u logorima. U svibnju 1943. sa suprugom, sinom i snahom deportiran u Auschwitz, gdje je ubijen.

GOLDSTEIN: Rukopis Židovskog biografskog leksikona. Rabinsko obrazovanje stekao je na Visokoj školi za židovske studije u Berlinu. Svoje je ideje o tome kako valja ustrojiti židovski život i židovske općine objavljivao u raznim časopisima antologijske vrijednosti u židovskoj publicistici. Predsjednik Židovskog Narodnog Akademskog Društva Judeja postaje 1923. Za rabina je imenovan 1929.; iste godine prihvaća službu u Osijeku, kao zamjenik nadrabina, a 1936. postao je zagrebački rabin. Najvažnije djelo, Molitvenik izdao je dvojezično 1938. Jedan od istaknutih članova Udruženja općih cionista u Jugoslaviji, osnovanog 1935. (zajedno s Aleksandrom Lichtom), a 1938. postaje drugi potpredsjednik SCJ. Iako je zagovarao odlazak u tadašnju Palestinu, sam nije odlazio jer je smatrao da kao rabin mora ostati sa svojom zajednicom. Zajedno s predsjednikom Općine Hugom Konom, bio je ključna osoba u ratnim naporima spašavanja židovske zajednice u Zagrebu i NDH. Krajem 1942. u posljednjem transportu djece u Palestinu poslao je i svog jedanaestogodišnjeg sina Rubena. U svibnju 1943. sa suprugom je deportiran u Auschwitz, gdje je ubijen. ŠELAĤ 1990: 311. Početkom 1942. godine, nakon bijega dotadašnjeg tajnika, Aleksandra Kleina u Italiju, rabin Miroslav Šalom Freiberger postaje i tajnik Općine. 
preostali zagrebački Židovi, koji nisu potpadali ni pod jednu zaštićenu kategoriju, vodstvo preuzimaju Robert Glücksthal (1887. - 1972.) ${ }^{27}$ i Oskar-Ašer Kišicky $(1899 .-1979 .)^{28}$, koji su bili oženjeni arijevkama te su na taj način bili izuzeti od deportacija. Općinu su nastavili voditi i nakon oslobođenja. ${ }^{29}$

Općina već 8. svibnja šalje nepotpisan dopis Ministarstvu unutarnjih poslova, u kojemu moli da se devetorici namještenika dozvoli daljnji nesmetani rad. Od te devetorice, njih četvorica prethodnih su dana uhićena i u međuvremenu vjerojatno i deportirana jer nisu preživjela rat. Osim toga, u dopisu se daje izvješće o dosadašnjem radu Općine te se predlaže da Općina i dalje nastavi rad kroz pet ustanova (općinski ured, matični ured, skrb za logore, pučka kuhinja te ambulanta za izdavanje lijekova), a istoga je dana i nadbiskup Stepinac uputio pismo ministru unutarnjih poslova Andriji Artukoviću, u kojem zahtijeva da se omogući slobodno djelovanje ŽBOZ-a. Za nadzor nad radom Općine bilo je nadležno Glavno ravnateljstvo za unutarnju politiku Ministarstva unutarnjih poslova NDH. ${ }^{30}$ Glavne aktivnosti Općine sastoje se od održavanja menze u Zagrebu, prehranjivanja staraca u staračkom domu u Brezovici i slanja paketa u logore. Općini je oduzeta zgrada u Trenkovoj 9, pa se skrb za logore preselila u

27 GOLDSTEIN: Rukopis Židovskog biografskog leksikona. Kao student 1909. izabran za perovođu Židovskog akademskog kulturnog kluba Judeja. Urednik lista Gideon, koji počinje izlaziti 1919. Diplomirao pravo, stekao i doktorat, od 1929. odvjetnik u Zagrebu. Kao pravnik bio član tzv. kontribucijskoga odbora - Odbora u stvari podavanja Židova za potrebe Države, osnovanog u svibnju 1941., da bi se od zagrebačkih Židova oduzelo $1.000 \mathrm{~kg}$ zlata. Nakon posljednje velike deportacije zagrebačkih Židova u svibnju 1943. preuzeo rukovođenje ŽBOZ-a, zajedno s Oskarom-Ašerom Kišickyjem. Bio je zaštićen jer je bio oženjen arijevkom. Godine 1945. sastavio temeljni izvještaj o događajima u zagrebačkoj židovskoj zajednici i židovskoj općini tijekom rata. Predsjednik ŽBOZ-a u Zagrebu do 1946. Čini se da su ga policijske službe sumnjičile za suradnju s neprijateljem za vrijeme rata, pa mu čak zbog toga pravili određene probleme. Sa suprugom Marijom r. Tscherner, sinom Oskarom i kćerima Elzom i Ruth 1948. emigrirao u Izrael.

28 GOLDSTEIN: Rukopis Židovskog biografskog leksikona. Činovnik i židovski aktivist. Tridesetih godina djelatan u raznim odborima JVO-a u Zagrebu, osobito u pogledu financija (predsjednik Upravnog odbora i dr.). Bio je djelomično zaštićen jer se supruga smatrala arijevkom. Poslije deportacija u svibnju 1943. preuzeo vođenje ŽBOZ-a, zajedno s Robertom Glücksthalom. Obitelj je potkraj četrdesetih emigrirala u Izrael.

29 Važno je napomenuti da se pojam mješovitog braka u ovom razdoblju upotrebljava kao rasna definicija, odnosno, prema rasnim zakonima, kao brak između arijevaca i nearijevaca. Budući da u Kraljevini Jugoslaviji, osim u Rijeci, Međimurju, Prekmurju, Baranji, Bačkoj i Banatu, između dvaju ratova nije bilo moguće sklopiti građanski brak, tako je (uglavnom) ženska osoba prelazila na religiju svog budućeg supruga (židovstvo se u Jugoslaviji definiralo kao religija), kako bi se takve osobe mogle međusobno vjenčati. Činom prelaska na židovstvo osoba postaje Židov, pa se ne radi o mješovitom braku. On je mješovit jedino za ustaške vlasti, odnosno za njihove rasne zakone. No, ta je činjenica od smrti spasila samo određen broj tzv. arijevaca $\mathrm{i}$ njihovih nearijskih članova obitelji. 
zgradu na Trgu kralja Tomislava; namještaj je Hrama pohranjen, a i bogoslužja su se nastavila na novoj adresi, na Tomislavovu trgu, pod vodstvom nadkantora Grünera. Prestaje djelovati i židovska škola jer je većina djece deportirana u Auschwitz. U gradu ostaju Židovi u tzv. mješovitim brakovima, Polužidovi, tzv. nežidovski Židovi, koji su bili oženjeni nežidovkama, kao i pojedinci zaštićeni po nekim drugim osnovama. Od staračkih domova ostao je onaj u Stenjevcu, koji je zahvaljujući zalaganjima zagrebačkog nadbiskupa Alojzija Stepinca preseljen na imanje i pod zaštitu Zagrebačke nadbiskupije u Brezovici. ${ }^{31}$

U arhivu Židovske općine u Zagrebu, koji se nalazi u Jevrejskom istorijskom muzeju u Beogradu, nalazi se građa o načinu konstituiranja ove ratne općine, popisi članova predloženog vijeća i ostalih tijela općine te njezinih službenika/namještenika, kojima je takva funkcija pružala osobnu sigurnost, kao i zaštitu članova njihovih obitelji te imovine, što se u pravilu i događalo do svibnja 1943. Svakako bi bilo zanimljivo istražiti koji su čimbenici uvjetovali izbor baš tih pojedinaca i unutarnju atmosferu oko tog izbora. Za nešto bi bilo moguće pronaći odgovore dubljim i temeljitijim istraživanjem arhiva Općine, no odgovore na neka pitanja sigurno nećemo nikada dobiti.

Ono o čemu se do sada u hrvatskoj historiografiji, koja se bavi razdobljem Šoa, nije nijansirano raspravljalo, svakako je diskrepancija između židovske identifikacije sadržaja židovstva i ustaške definicije pojma Židov, točnije židov. Naime, među Židovima, prema rasnim kriterijima, našao se određen broj osoba, kojima su već očevi prešli na katoličanstvo. Neki su od njih i sami gajili antisemitske stavove. U svjetskoj se historiografiji tek relativno nedavno počelo diferencirati Židove i nežidovske Židove te proučavati odnose između njih, suživot u getima, nijansiranje njihova položaja s obzirom na to jesu li bili polužidovi koji su bili u braku sa Židovima ili arijevcima itd. Zato bi bilo zanimljivo istražiti sve one osobe, kojima tijekom rata, kao članovima ŽBOZ-a, pišu ratna vodstva Općine, kako bi im oni platili doprinose Općini, i analizirati tko je od njih bio član Općine prije rata, a tko je to postao slijedom ustaških rasnih zakona. ${ }^{32}$

\section{Povratak preživjelih hrvatskih Židova}

Nemoguće je utvrditi točne podatke o broju Židova na području Hrvatske prije Drugog svjetskog rata. Židovska bogoštovna općina u Zagrebu raspolaže s

31 GOLDSTEIN 2001: 552-558.

32 Ta se distinkcija rijetko navodi u znanstvenim člancima (GOLDSTEIN 2002: 446), no u izvornoj je građi vidljivija: JIM, arhiv ŽOZ, razna mjesta; KEVO 2009: 43-61. U jednom takvom dokumentu predsjednik ŽBOZ-a Hugo Kon navodi da je prije zadnjih deportacija u kolovozu 1942. u Zagrebu ostalo 750 čistih Židova, po vjeri i podrijetlu, i 850 osoba židovskog podrijetla. GRBEŠIĆ 2003: 165. Autor navodi da je u logoru u Đakovu bilo smješteno oko 3.000 osoba, od kojih su većina žene i djeca. Od toga broja bilo je oko 700 pokrštenih Židova. 
podatkom od 22.310 članova predratnih židovskih općina na području Hrvatske. Prema Jaši Romanu, prije rata na području Hrvatske, Slavonije i Srijema živjelo je 25.000, a Dalmacije 400 Židova; navodi podatak od još 1.500 Židova u Sloveniji, Međimurju i Prekmurju. Baranja se u njegovoj statistici navodi s Bačkom sa 16.000 Židova, od kojih je većina živjela u Bačkoj. Isti se problem javlja pri procjenama broja preživjelih. Jaša Romano navodi 5.000 preživjelih u Hrvatskoj, Slavoniji i Srijemu, 252 u Dalmaciji, a 200 u Sloveniji, Međimurju i Prekmurju. On svoje procjene temelji na osnovi poslijeratnih publikacija, malog broja sačuvanih dokumenata i izjava preživjelih te napominje da su podaci samo djelomično točni. ${ }^{33}$

Ivo Goldstein u monografiji Holokaust u Zagrebu i članku „Istraživanje židovskih žrtava: razmatranja o Zagrebu i Hrvatskoj te Genocid nad Židovima u $\mathrm{NDH}^{\text {“ }}$ svoje procjene temelji uglavnom na procjenama Jaše Romana. ${ }^{34}$ Marica Karakaš Obradov navodi da je na hrvatskom području prije početka Drugoga svjetskog rata, prema procjenama, živjelo između 23.000 i 26.000 Židova, a na bosansko-hercegovačkom području oko 14.000 Židova. Ona navodi i različite procjene preživjelih, uspoređujući podatke koje iznose izvori te kasniji autori (Milan Ristović, Ivo Goldstein, Slavko Goldstein, Esther Gitman i dr.), što je za NDH između 9.000 i 12.000. Ivo Goldstein navodi da je na području sjeverne Hrvatske, Slavonije, Srijema i Dalmacije preživjelo 5.250 Židova (odnosno 9.000 na području NDH). No, za preživjele u partizanima navodi samo procjene za područje NDH (2.339). Esther Gitman navodi da je oko 9.500 Židova s područja NDH preživjelo Šoa. Autorica ističe da je bilo i onih koji su se odbili prijaviti Općini u Sarajevu, pa možemo pretpostaviti da je takvih slučajeva bilo i na područjima drugih židovskih općina. Bilo je i onih koji su od 1944. odlazili u Mandatnu Palestinu, SAD i druge zemlje. Brojni su bili uključeni u poslijeratne strukture vlasti i živjeli u Beogradu, a neki su promijenili prezimena i odmaknuli se od židovskih institucija i identiteta. ${ }^{35}$

Od $20-25 \%$ preživjelih samo je nekolicina židovskih logoraša preživjela Jasenovac i Auschwitz. Malen je broj Židova preživio na teritoriju pod izravnom ustaškom vlašću, a i to je bilo slučajno ili zahvaljujući njihovoj posebnoj dovitljivosti ili dovitljivosti ljudi iz njihove okoline, koja ih je na različite načine spašavala. Ovdje

33 JIM, fond ŽOZ, inv. br. K.63-3-3/1-163: Općina 18. rujna 1945. šalje statističke podatke kojima raspolaže Zemaljskoj komisiji za utvrđivanje zločina okupatora i njihovih pomagača. Podaci se odnose na članove bivših ŽBO-a na području Federalne Hrvatske (22.310) te na području Bosne i Hercegovine (10.936), što je ukupno 33.246 za teritorij bivše NDH; u dopisu se napominje da u taj broj nisu uključeni emigranti, kojih je moglo biti oko 1.000, kao ni oni koji su potpali pod rasne zakone, a nisu zabilježeni u podacima židovskih općina, te se procjenjuje da bi taj broj bio oko 35.000. ROMANO 1980: 201.

35 GITMAN 2012: 26, 66; KARAKAŠ OBRADOV 2013: 175-176; Ista 2014: 262-266. 
treba pribrojiti i brojku od oko 800 osoba, koje su u Zagrebu preživjele zahvaljujući činjenici da su bile u mješovitim brakovima ili su pripadale nekoj drugoj štićenoj skupini. U drugim dijelovima NDH preživjelo je jedva sto ili dvjesto Židova. Dio ih je preživio i na teritorijima pod talijanskom kontrolom, dok je najveći broj preživio u partizanima ili na teritorijima pod partizanskom kontrolom. ${ }^{36}$ Prema Marici Karakaš Obradov, na teritoriju NDH preživjelo je oko 500 počasnih arijevaca (oni koji su na razne načine, prema mišljenju vlasti NDH, zadužili hrvatski narod i članovi njihovih obitelji). Zatim su tu bili Židovi u mješovitim brakovima, za koje se osobito zauzela Katolička crkva, i takvih je u Zagrebu bilo oko 1.000. Zagrebački nadbiskup Stepinac na crkvenom imanju smjestio je štićenike židovskog staračkog doma zaklade Lavoslava Schwarza i tamo ih je 55 dočekalo kraj rata. U Osijeku je ostalo između 140 i 300 - 360 Židova koji su bili u tzv. mješovitim brakovima (vjerojatno je razlika nastala zbog neubrajanja članova obitelji), a prema drugim procjenama još je oko 300 Židova iz osječke okolice preživjelo rat. Židova koji su kao obrazovani liječnici, inženjeri i sl. dobili arijsko pravo i preživjeli rat, prema različitim procjenama, bilo je između 300 i nekoliko tisuća. ${ }^{37}$

Nakon oslobođenja počinje povratak u prijeratnu domovinu, no često ne $u$ mjesta prijeratnog prebivališta. Manji se dio vraća iz vojnog zarobljeništva, gdje su završili kao vojnici ili časnici kraljevske vojske 1941.; dio je preživio njemačke koncentracijske logore, dio je bio u partizanima ili na oslobođenim teritorijima te se dio nalazio u Italiji i drugim zbjegovima, dok je najmanji dio preživio skrivajući se na teritoriju bivše NDH. Ubrzo nakon oslobođenja Beograda, 3. prosinca 1944., otprilike 3.000 židovskih interniraca u Italiji dobilo je naredbu o povratku u matičnu zemlju. ${ }^{38} \mathrm{U}$ slučaju odbijanja povratka prijetio im je gubitak državljanstva. Prema izvješću djelatnika Jointa, Cvija Leimana, iz prosinca 1944., sačuvanog u Središnjem cionističkom arhivu u Jeruzalemu, većina ih se htjela vratiti kako bi sačuvala svoju imovinu, iako dobar dio imovine ili prijeratnih tvrtki, odnosno djelatnosti, više nije ni postojao; istovremeno su se bojali posljedica gubitka državljanstva. ${ }^{39}$ Svi se ovi povratnici vraćaju u vrlo sličnu situaciju porušene, opljačkane ili zauzete imovine, često kao jedini preživjeli članovi obitelji, ne nužno i u njihova prijeratna prebivališta. ${ }^{40}$

36 GOLDSTEIN 2001: 636-648; Isti 2002: 445-463.

37 KARAKAŠ OBRADOV 2013: 177.

The American Jewish Joint Distribution Committee humanitarna je židovska organizacija sa središtem u New Yorku, SAD. Osnovana je 1914. i danas je aktivna u 70 država. Poznata je i po svojim akronimima, JDC ili Joint.

40 Za njihovo profiliranje, dok su još bili u Italiji, pobrinula se OZN-a, koja je svoj odjel imala u Italiji. U arhivu OZN-e u Italiji, koji se čuva u Hrvatskom državnom arhivu u Zagrebu, nalazi 
Procjene broja preživjelih zagrebačkih hrvatskih Židova kreću se između 2.214 do preko 3.000. Njih oko 1.000 vratilo se u grad, kamo se doselilo otprilike 1.000 Židova, koji su prije rata živjeli negdje drugdje. Ovdje se opet postavlja pitanje metodologije: jesu li u taj broj ubrojeni i pokršteni Židovi, koji se prije Šoa nisu smatrali Židovima, ali su ih tako klasificirali rasni zakoni, ili oni koji se nakon rata nisu vratili na židovstvo. Prema podacima iz arhiva ŽOZ-a, nešto više od 600 Židova nakon rata vratilo se na židovstvo. ${ }^{41}$ Prema Davidu Pereri, Židovska bogoštovna općina u Zagrebu (ŽBOZ) neposredno nakon rata imala je 2.126 članova ${ }^{42}$

\section{Aktivnosti Židovske bogoštovne općine u Zagrebu nakon svibnja 1945.}

Iako je Općina odmah na početku rata bila izbačena iz svojih prostorija, ona je od svibnja 1941. godine kontinuirano radila, što je sigurno olakšalo povratak preživjelih u Zagreb, a vjerojatno i uvjetovalo dolazak Židova, koji su prije rata imali neko prebivalište. Prema aktivnostima Općine, koje je ona organizirala u neposrednom poraću, očigledno je da je Općina nastavila funkcionirati kao za vrijeme rata: brinula se za starce u staračkom domu, imala je pučku kuhinju, ordinaciju i ljekarnu, a nastavila je i dužnost vođenja matičnih knjiga. U novoj situaciji počela je organizirati i dvije nove aktivnosti: prihvatilište za povratnike te potragu za preživjelom židovskom djecom, koja su bila udomljena kod raznih pojedinaca, obitelji i ustanova širom Hrvatske. U tekstu koji slijedi opisuje se i niz konkretnih oblika pomoći, koje je Općina pružala svojim i članovima u drugim dijelovima Hrvatske i Slovenije. Dotadašnje dopisivanje s rodbinom logoraša sada je zamijenila intenzivna korespondencija, u kojoj su Židovi iz inozemstva i Jugoslavije pokušali locirati preživjelu rodbinu ili svoju imovinu.

Odmah nakon završetka rata ŽBOZ funkcionira kao svojevrsna zrcalna slika beogradskog Saveza jevrejskih veroispovednih opština Jugoslavije, brinući se, u prvom redu, za povratnike u Zagreb i Hrvatsku. Nakon obnove općina u Osijeku, Splitu i Čakovcu, nastavlja se brinuti ne samo za Židove iz Zagreba i okolice, već i za Židove iz gradova u kojima nije došlo do obnove općina te dalje služi kao svojevrstan logistički centar hrvatskih Židova. ${ }^{43}$

se niz dokumenata o saslušavanju pojedinaca, koji se tada nalaze u jugoslavenskoj bazi u Bariju. Različiti su razlozi saslušavanja: rutinski se provode saslušavanja osoba, koje se javljaju u bazu u Bariju, a dolaze iz različitih dijelova Italije, gdje su se dotad skrivali, no ima i saslušavanja osoba koje su drugi prijavili u bazi ili su sumnjivi zbog puke presrdačne komunikacije sa zapadnim saveznicima. HR-HDA-1491, OZNA Hrvatske, 14: serija fonda OZN-e označena brojem 14 odnosi se na bazu OZN-e za Italiju.

41 JIM, arhiv ŽOZ, Spiskovi preživelih Jevreja, 264-332; HDA, fond ZKRZ GUZ, br. 306, kut. 15, 3871; JIM, arhiv ŽOZ, obrasci za istup iz rimokatoličkih župa u Zagrebu.

42 PERERA 1970: 135-147.

43 JIM, arhiv ŽOZ, sign. K. 63-3-2/1-9. 
Jedno od prvih pitanja s kojim se susreće vodstvo Općine u neposrednom poraću jest odgovor na pitanje tko je Židov, s obzirom na to da je definicija u Kraljevini Jugoslaviji bila religijska, shvaćanje koje se nastavlja i nakon rata. U svjetlu činjenice da je oko polovina preživjelih Židova u jednoj fazi neposredno pred rat ili za vrijeme rata bila pokrštena, razmišljalo se o tome na koji se način Općina treba postaviti da bi dobila natrag svoje članove. Odlučeno je da se takva krštenja, za one koji izraze želju biti članovi židovskih općina, smatraju ništavnima i da se članovima pomogne da se ispišu iz župa u kojima su kršteni. Brojne je dopise Općina poslala župama i crkvama raznih kršćanskih denominacija, gdje se traži da se pokršteni Židovi ispišu iz njihovih knjiga krštenih, kako bi ponovno mogli postati članovi židovskih općina. Općina je tiskala formulare Vraćanje , užidovsku vjeru “, gdje u naslovu stoji Židovska bogoštovna općina u Zagrebu, a u tekstu: ...prilažem moj dopis na Župni ured (popuniti) u kojem isti obavješćujem o mome povratu sa rimokatoličke na židovsku vjeru, pa molim, da taj povrat na židovsku vjeru izvolite zabilježiti u matičnim knjigama vaše općine. Ispod zadanog teksta slijedi mjesto za popunjavanje osobnih podataka (ime, datum i mjesto rođenja, imena roditelja, točna adresa te dvoje svjedoka ${ }^{44}$. Taj se postupak primjenjivao kada se radilo o pojedinačnim konverzijama, gdje su pojedinci tražili ispis iz trenutačne vjeroispovijesti, međutim dio povratnika smatrao je da se sve konverzije provedene za vrijeme NDH trebaju smatrati ništavnima. Tako Mojsije Trilnik, povratnik na područje zapadne Slavonije, u svom izvješću o broju i situaciji preživjelih Židova za Kutinu i okolicu (Čazmu, Ivanić Grad, Vojni Križ, Banovu Jarugu, Novsku i Popovaču), Novu Gradišku i okolicu, Pakrac, Lipik, Kukunjevac, Dobrovac i Daruvar konstatira da su popisani članovi predratnih općina ne samo pokradeni,

44 Niz dopisa različitim zagrebačkim župama s različitim datumima, najviše župama sv. Petra, sv. Blaža i sv. Duha. JIM, arhiv ŽOZ, sign. K.60-5-1/1-18 od 13. rujna 1945: Dopis Nadrabinata Rimokatoličkom župnom uredu Sv. Blaža o najavi povrata u židovsku vjeru (na spisku i Mirjam Gross). Ovakvi dopisi upućivali su se i drugim rimokatoličkim župama, npr. JIM, arhiv ŽOZ, sign. K.60-5-1/1-26, K.60-5-1/1-30: za dijete Borisa Engela, rođeno 1944., od židovskog para, muž stradao u Jasenovcu...); JIM, arhiv ŽOZ, sign. K.60-5-1/1-2 do 11 (kolovoz-rujan 1945.); JIM, arhiv ŽOZ, sign. K.60-5-1/1-1; JIM, arhiv ŽOZ, sign. K.60-5-1/1-14 i 15 (oba 13. rujna). Vidi skupnu listu JIM, arhiv ŽOZ, sign. K.60-5-1/1-99 s 35 imena osoba koje se vraćaju u židovsku vjeru, a dopis je ŽBOZ uputila rimokatoličkoj Župi sv. Petra. Dopisi idu i prema Evangeličkoj crkvenoj općini (JIM, arhiv ŽOZ, sign. K.60-5-1/1-32) i Anglikanskoj crkvi (JIM, arhiv ŽOZ, sign. K.60-5-1/1-34), a postoji i dopis Slovenske starokatoličke crkve u Ljubljani Nadrabinatu, u kojem ga ova obavještava da je u svojim knjigama zabilježila prijelaz Ferdinanda Glücksa natrag na židovsku vjeru (JIM, arhiv ŽOZ, sign. K.60-5-1/1-143) od 30. rujna 1945. Vidi i JIM, arhiv ŽOZ, sign. K.60-5-1/1-57 od 14. srpnja 1945., gdje majka Ana, rođ. Weiss, obavještava ŽBOZ da njezin sin Adolf Fanto, rođen 1935. u Beču, pristupa židovskoj vjeri, a dodana je i naknadna bilješka da je upisan u knjigu pristupa. Vidi i K.60-5-1/1-49, K.60-5-1/1-63 itd. Molbe za ponovno primanje u židovsku vjeru dolaze i iz inozemstva, npr. JIM, arhiv ŽOZ, sign. K.71-1a-2/7 Bruna Eremića, supruge Marge i kćeri Nevenke iz Švicarske za ponovno primanje u ŽBO, iz koje su istupili 5. srpnja 1941. 
već su uglavnom pokršteni te da bi se velik dio vratio židovskoj vjeroispovijesti. On smatra da se eventualni povratci ne bi trebali tretirati pojedinačno, već da bi se ova situacija trebala riješiti na način na koji je to riješila Srpska pravoslavna crkva, a to je naredba o poništenju svih krštenja nastalih od 1941. do tada. Za njega je to način da se pojedinci poštede daljnjih stresova s tim u vezi jer je, kako kaže, duhovno stanje potišteno, no polažu nadu u budućnost... ${ }^{45}$ Bilo je i onih koji se nisu željeli vratiti u židovstvo, poput Pavla Becka, koji je pred činovnicom ŽBOZ-a, Margitom Roth, izjavio da nije voljan pristupiti natrag u židovstvo jer je to u suprotnosti s njegovim političkim uvjerenjima, a dopušteno je biti bezvjerac. On se ipak zahvaljuje navedenoj općini na pomoći koju mu je pružala u najtežim danima da se održi na životu i spreman je općinu i nadalje moralno i materijalno potpomagati, čim za to bude imao materijalnih mogućnosti. Možda je ta izjava dana u kontekstu izdavanja slobodnog lista (dokument potreban za sklapanje braka), koji je Pavlu Becku morao izdati Nadrabinat kao voditelj matica. ${ }^{46}$

\section{Socijalna djelatnost}

Najveće napore i sredstva ŽBOZ ulaže u rješavanje smještaja i prehrane povratnika, pa se osnivaju dormitorij u Haulikovoj 6 (već u svibnju), menza te ambulanta pri Općini, koja od kraja lipnja ponovno funkcionira u svojim prostorijama u Palmotićevoj 16. Posebnu kategoriju među povratnicima čine bivši logoraši, koji se vraćaju iz njemačkih logora. Za njih su posebno bile zadužene činovnice Općine, Margita Roth i Blanka Pollak. ${ }^{47} \mathrm{O}$ njima se Općina brine na poseban način, pa se navodi da povratnici u svemu imaju prednost pred koštašima te se izričito nalaže da prema povratnicima treba biti pažljiv, obziran i strpljiv, bez nervoznih ispada i lekcija. ${ }^{48}$ Prihvatilištu, menzi i ambu-

45 JIM, arhiv ŽOZ, sign. K.63-3-2/1-150 od 17. srpnja 1945.

JIM, arhiv ŽOZ, sign. K.60-5-1/1-16 od 13. kolovoza i K.60-5-1/1-16-17 te od 21. rujna 1945.

JIM, arhiv ŽOZ, sign. K.63(73)1II-1A/1 i drugi dokumenti bez signature i reg. br., uglavnom u kut. 63. Budući da se broj povratnika, među njima i logoraša, svakim danom povećava, Općina se kod lokalnih i državnih organa vlasti zauzima i za povratak stanova i kuća svojih članova, koji radi toga borave u zajedničkoj općinskoj spavaonici. Sačuvan je dopis od 28. rujna 1945. (no, nije jasno kome), da se povratnici Štefaniji Neumann, koja trenutačno spava u zajedničkoj spavaonici u Palmotićevoj, a pritom stalno stižu novi bivši logoraši, omogući da se vrati u svoju kuću (JIM, arhiv ŽOZ, sign. K.63(73)1II-1A/1).

48 JIM, arhiv ŽOZ, sign. K.63(73)1II-1A/1 od 6. lipnja 1945. Konkretan dopis poslan je menzi, a upute da prema povratnicima treba biti pažljiv, obziran i strpljiv... podvučene su. S obzirom na to da su članovi židovske zajednice bili svjesni posebne situacije povratnika iz nacističkih logora, bilo bi zanimljivo istražiti razlike između tretiranja povratnika od strane židovskih zajednica i same države, kako u Hrvatskoj i Jugoslaviji, tako i u drugim europskim zemljama. Koštasi su oni koji se hrane u menzi, uglavnom uz novčanu naknadu (od njem. Kost, hrana, redovita prehrana). 
lanti, ali i ostalim povratnicima neophodno su bili potrebni kreveti, pokrivači, hrana i odjeća te drugo. Općina od ekonomskog odjela Komande Pozadine II. Jugoslavenske armije dobiva 50 garnitura željeznih kreveta i dasaka za uređenje židovskog prihvatilišta, a od Crvenog križa 80 slamarica i, pred zimu, ukupno 30 popluna i deka. Iz dokumenata je vidljivo da ŽBOZ traži način kako riješiti situaciju u kojoj državne vlasti, kod zamjene za dinare, stranu valutu preračunavaju po izuzetno nepovoljnom tečaju, stoga traže da međunarodne židovske organizacije, umjesto u novcu, šalju pomoć u odjeći, obući, krevetnini i ostalim potrebnim predmetima, u iznosu koji je predviđen za pomoć Jugoslaviji. ${ }^{49}$ No, židovske su organizacije (Sohnut, World Jewish Congress) i naročito Joint, koji je financirao gotovo cjelokupnu židovsku aktivnost u Jugoslaviji koristile potrebu jugoslavenskih vlasti za devizama, s obzirom da je Jugoslavija bila pod financijskim bojkotom od strane Zapada, kako bi dobili određene ustupke za neke djelatnosti, naročito one vezane uz organizaciju ilegalnog useljavanja iz Europe u tada Mandatnu Palestinu (alijá bet)..$^{50}$

Židovska bogoštovna općina u Zagrebu djelovala je i kao svojevrsno povjerenstvo za repatrijaciju židovskih izbjeglica, koje su na raznim lokacijama čekale povratak kućama. Na teritoriju pod kontrolom ZAVNOH-a u tom razdoblju djeluje Komisija za skrb Jevreja, na čijem čelu stoji Aleksandar Piliš, koji je 1941. bio uključen u tzv. Kontribucijski odbor. ${ }^{5 l}$ Povratnici su tijekom 1944. iz područja oko Gline i Topuskog krenuli prema Dalmaciji, odnosno prema Bariju. Iz Italije i Dalmacije su se, nakon oslobođenja, počeli vraćati svojim kućama i u Zagreb. No, početkom svibnja 1945. Komisija za skrb Jevreja u Topuskom piše Većeslavu Holjevcu, komandantu Zagreba, u kojem ga obavještava da je, nakon odlaska većeg dijela zbjega prema Dalmaciji, na Kordunu ostalo još oko 320 članova židovskog zbjega i to u Topuskom i okolici njih oko stotinu, Glini i okolici oko dvije stotine i Kordunskom zagorju oko dvadeset te čekaju povratak kućama. Za povratak su im potrebne putne isprave, prijevozna sredstva i određeni pravci povratka. Deset dana kasnije Predstavništvo Jevreja u Glini moli ŽBOZ da kod Narodne vlade poduzme korake kako bi se izbjeglice vratile svojim kućama. ${ }^{52}$ Nakon toga Komisija za zbrinjavanje Jevreja u Topuskom

49 JIM, arhiv ŽOZ, sign. K.63-2-1/1-223 i drugi dokumenti s tim u vezi (molba Komandi Pozadine II. JA); JIM, arhiv ŽOZ, sign. K.63(73)-1-1A/1 od 27. studenog 1945. (dopis Carini PTT-a); JIM, arhiv ŽOZ, sign. K.63-2-1/1-296 bez datuma (pismo Artura Krausa Robertu Glücksthalu).

50 ك̌ELAH 1994: 153-154. Sohnut/The Jewish Agency for Palestine osnovan je 1908. pod imenom Ured za Erec Israel (המשרד הארץ-ישראלי/The Palestine Office).

51 PAVER 1989. U sastavu fonda ZAVNOH-a ova se komisija naziva Komisija za evakuaciju i skrb Jevreja. Osnovana je 1943. kao Komisija za evakuaciju i skrb Jevreja u kontekstu evakuacije Židova s Raba nakon kapitulacije Italije u rujnu 1943. 
dobiva hitnu novčanu pomoć od ŽBOZ-a za sve potrebite Židove koji se još nalaze u Topuskom (gotovina od milijun kuna). Novčana pomoć stiže sa svih strana, pa je tako Općina evidentirala i razne uplate od međunarodnih židovskih organizacija, kao i pomoć od Komisije za skrbi Jevreja za pojedince od po 20.000 dinara po osobi, a bilo je i skupnih uplata (300.000 dinara za petnaest osoba u Bjelovaru)..$^{53}$

Niz dopisa u općinskom arhivu tiče se evidencije i pozivanja, odnosno javljanja liječnika na volontiranje u Općini, potom opskrbe ambulante lijekovima i materijalom te slanja pacijenata na liječenje pojedinim židovskim liječnicima. ${ }^{54}$ Velik broj preživjelih povratnika bolovao je od tuberkuloze, a mnogi se nisu mogli koristiti rukama ili nogama. U naporima da se zdravstveno pomogne članovima općine, bivši veletrgovac iz Zagreba Iso Weiss izrazio je spremnost da sve popravke i naočale po receptu izradi besplatno, ukoliko ima stakla na skladištu. ${ }^{55} \mathrm{Uz}$ sve to, Općina je kao odgovor na molbe članovima u Zagrebu, ali i u drugim gradovima potvrđivala status ratnog stradalnika, pružala im socijalnu pomoć, davala pravo na prehranu u menzi i slično. ${ }^{56}$

Druga najugroženija kategorija članstva Općine bili su stariji i nemoćni, za vrijeme rata smješteni na imanju Zagrebačke nadbiskupije u Brezovici, gdje su dočekali i kraj rata. Općina se brinula o njihovu smještaju u domu, prehrani, liječničkoj skrbi, a dom je posjećivala i omladina, koja je izvodila prigodne programe, kako bi im olakšala boravak u neadekvatnim uvjetima, s obzirom na to da im zgrada nekadašnjeg doma zaklade Lavoslava Schwarza, iz koje ih je izbacila ustaška vlast, još nije bila vraćena. Općina je bezuspješno pokušavala vratiti tu zgradu, no nije uspjela u tome. ${ }^{57}$ Općina se suočavala i s problemom isplata mirovina. Tako se u Zagreb iz Švicarske vratila i udovica nekadašnjeg nadrabina

$\overline{52}$ JIM, arhiv ŽOZ, sign. K.63-2-1/1-43 od 11. svibnja 1945. U Zagreb povratak čeka njih oko 180, u Osijek oko 50, Bjelovar 10, Banju Luku 5, Ogulin 5, Slavoniju 10, na prugu Brod - Sarajevo oko 50, a u Vojvodinu se vraća njih 10. Komisija za skrb Jevreja i Odbor za zbrinjavanje Židova jedno je te isto tijelo, koje se u dopisima češće nalazi kao Komisija nego kao Odbor. JIM, arhiv ŽOZ, sign. K.63-2-1/1-265 od 21. svibnja 1945.

53 JIM, arhiv ŽOZ, sign. K.63(73)1-1A/1. različitih datuma od Komisije za skrb Jevreja; JIM, arhiv ŽOZ, sign. K.63-2-1/1-250 od 18. svibnja 1945. Vidi i K.63-2-1/1-60, K.63-3-1/1-7, K.63-31/1-146 i K.63-3-1/1-81, sve iz lipnja i srpnja 1945. JIM, arhiv ŽOZ, sign. K-63-2-1/1-63 sadrži obavijest o dospijeću sredstava koje uplaćuje SJVOJ-Autonomni odbor (Joint u Jugoslaviji). U različitim dokumentima ŽBOZ-a i Komisije izmjenjuju se kune i dinari. JIM, arhiv ŽOZ, sign. K-63(73)-1II-1a/1. U ovoj je kutiji i fotografski materijal o ambulanti unutar Općine.

JIM, arhiv ŽOZ, sign. K-63-3-3/1-71 od 21. studenog 1945.

56 JIM, arhiv ŽOZ, kut. 63, F1, razno iz 1945.

57 JIM, arhiv ŽOZ, sign. K.63-3-4a/1-13 i brojni drugi dopisi te dokumenti bez signature i reg. br. u kut. 63. Odgovor državnog tijela na dopis Općine za povrat zgrade doma od 18. rujna jest dopis JIM, arhiv ŽOZ, sign. K.63-3-3/1-28 od 24. rujna 1945. 
Gavre Schwarza, Frieda, koja je od općine zatražila suprugovu rabinsku mirovinu. Istovremeno je od jugoslavenske države zatražila mirovinu koju je on zaradio kao srednjoškolski profesor. Iz arhiva Općine ne vidi se je li u tome uspjela. Općini se iza rata javila i Ella Schick/Šik, supruga ubijenog dr. Lavoslava Schicka/Šika, odvjetnika i jednog od najistaknutijih cionista u međuratnom razdoblju te svojevrsnog utemeljitelja judaistike u Hrvatskoj, koja je tražila različitu dokumentaciju vezanu za smrt njezina supruga, vjerojatno u postupku povrata imovine ili kako bi dobila njegovu mirovinu. I sama Općina pokreće pitanje svojih uložaka mirovinskog fonda, zadnje evidentiranih 18. travnja 1941., Zemaljskom zavodu za socijalno osiguranje Hrvatske. ${ }^{58}$

\section{Potraga za udomljenom/skrivenom djecom}

Židovska bogoštovna općina bavila se i potragom za udomljenom i skrivenom židovskom djecom. Ovom se problematikom počinje baviti odmah nakon završetka rata, no taj posao nije bio nimalo lagan, s obzirom na to da često nije bilo preživjelih članova obitelji, koji bi uopće znali gdje se nalaze djeca, ili su i sama djeca bila premlada da bi nešto znala o svom identitetu. Udomitelji nisu uvijek bili spremni otkriti identitet djece koju su sklonili jer su se tijekom rata vezali uz njih. Brojni su primjeri problema, no najčešći su bili oni oko nepoznavanja obiteljskog prezimena. Ovdje sam izdvojila samo neke. Tako je Općina već 18. srpnja 1945. poslala dopis Rozi Tkalec iz Ludbrega da pokuša saznati jesu li Dankici poznata imena njezinih roditelja. Dankica je, kao djevojčica od otprilike osam godina, smještena kod Roze Tkalec 1942. od strane Zagrebačke nadbiskupije. Istog dana Općina je poslala dopis i Dragi Schmidlehner u Ludbregu, u kojem traže Danka, starog oko 10 godina, koji se nalazio kod nje od 1942. Došao je k njoj zahvaljujući pomoći Zagrebačke nadbiskupije. Općina je pitala je li on upoznat s imenima svojih roditelja, odnosno je li brat Dankice, smještene kod Roze Tkalec. U dosad istraženoj arhivskoj građi nisam mogla zaključiti kako je ovaj slučaj završen. ${ }^{59}$

Bilo je i slučajeva gdje su bili poznati obiteljski podaci djece. Tako u rujnu 1945. upraviteljica Doma u Šestinama, časna sestra Sofija Radaić, piše Židovskoj bogoštovnoj općini, tražeći eventualno preživjelu rodbinu Nadice Goldberger,

$\overline{58}$ JIM, arhiv ŽOZ, sign. K.63-3-2/1-91 od 1. rujna 1945. O njezinu ratnom putu, gdje Općina potvrđuje da je Frieda Schwarz pred okupacijom u svibnju 1942. pobjegla u Italiju te 1943. prešla u Švicarsku, vidi i JIM, arhiv ŽOZ, sign. K.63-3-2/1-90 od 17. listopada; JIM, arhiv ŽOZ, sign. K.63-3-1/1-144 od 14. rujna 1945. (Ella Schick); JIM, arhiv ŽOZ, sign. K.63-3-3(?)/1-164 od 7. kolovoza 1945. u vezi s podacima mirovinskog fonda.

59 JIM, arhiv ŽOZ, sign. K-63-3-2, dopis ŽBOZ od 18. srpnja 1945.; JIM, arhiv ŽOZ, sign. K-633-2/1-1, dopis od 18. srpnja iste godine. 
rođene 1934., kćeri Mirka i Eme, rođ. Epstein, iz Vinkovaca. U dopisu njezina tadašnja skrbnica poimenice navodi sve njezine rođake, tražeći da joj se zaštiti imovina te moli da dijete ostane kod nje do punoljetnosti, ukoliko mu se ne nađe najbliža rodbina. Nada je u samostanu u Šestinama živjela tri godine i ondje je pokrštena. Nakon oslobođenja samostan je oduzet časnim sestrama i pretvoren u dom, u kojem se u trenutku potrage nalazila Nadica. Općina se uključila u traženje njezine obitelji. Najprije su pisali Kotarskom općinskom sudu za Grad Zagreb o tutorstvu nad Nadom Goldberger te su dobili informacije iz Vinkovaca s popisom i stanjem imovine obitelji Mirka Goldbergera i njegova tasta Mavre Epsteina. U poslanom dopisu nalaze se informacije o sudbini obiju židovskih obitelji za vrijeme Drugog svjetskog rata te podatak da su Nadičini krsni kumovi vlasnici tvornice octa u Vinkovcima živi i da je to obitelj Nad. Cijela je Nadičina obitelj stradala u logorima, a ona je smještena kod obitelji Nad. ${ }^{60}$

Ukoliko nije bilo preživjelih članova obitelji, djeca su ponekad ostajala kod skrbnika, pa je Općina novčano i na druge načine pomagala skrbnicima i djeci. Tako je novčano i u odjeći pomagala Mariji Nikolić iz Vukovara, skrbnici djevojčice Batje Scheer, kćeri vukovarskog rabina; zanimala se za njezinu situaciju, a djevojčica je i sama pisala Općini. Potkraj godine skrbnica Mirjana Nikolić iz Vukovara šalje zahvalu na novčanoj pomoći, koju je primila za djevojčicu. ${ }^{61}$ Ukoliko su skrbnici bili siromašni, za njih i djecu bili su organizirani besplatni obroci u općinskoj menzi. ${ }^{62}$

Kao što je bilo rečeno na početku ovog odlomka, većina udomitelja ili skrbnika nije se tako lako željela rastati s djecom, koju su smatrali svojom, pa se nisu javljali vodstvu ŽBOZ-a da su djeca kod njih, a mnogi od njih nisu ni znali identitet udomljene djece, pa su u početku primjeri povratka bili neznatni. Zbog toga je zagrebački liječnik, dr. Lavoslav Glesinger, u studenom 1945. pisao predsjedništvu

$60 \quad$ JIM, arhiv ŽOZ, sign. K.63-1-1/1-177. Dopisi od 7. kolovoza do 19. rujna 1945. Vidi i JIM, arhiv ŽOZ, sign. K.63-1-1/1-173 i 175, 176, 179 o naporima općine. ŠALIĆ 2002: 103-106. U podacima iz arhiva ŽOZ-a i podacima kojima raspolaže Šalić ima velikih nepodudarnosti. Budući da je 1947. obitelj Nad u kuću morala primiti jednu partizansku obitelj, Nadica je, umjesto u nekom samostanu, uz pomoć uglednog vinkovačkog Židova Armina Borovica završila u židovskom dječjem domu u Beogradu. U međuvremenu se otkrilo da ima živog rođaka Milana Hiršla, koji se spremao za iseljenje u Izrael te je s njim i otišla 1949.

JIM, arhiv ŽOZ, sign. K.63(73)1II-1A/1.

JIM, arhiv ŽOZ, sign. K.63-2-1/1-104. Već 23. svibnja 1945. skrbnica Dragica Jureković iz Vlaške moli za besplatan ručak i večeru za nju i njezine štićenice, siročad Leu Kohn, rođ. 1935., Ladislava (u ovom dokumentu naveden kao Lacay, rođ. 1938.) i Nadu Deutsch, rođ. 1941./1942. (u ovom se dokumentu navode kao Dajč). Više o ovoj djeci vidi u GOLDSTEIN 2001: 436 i ŠALIĆ 2002: 75. Goldstein navodi da su djeca u rujnu 1942. dovedena iz Vinkovaca, odnosno izvučena iz Loborgrada te smještena kod Dragice Jureković (rođ. Kohn) u Vlaškoj 70d. Šalić navodi da je Ladislav zbog bolesti prije uhićenja odveden u Zagreb u bolnicu i zadržan kod tetke, a kćerkicu Nadu majka je u svibnju ili lipnju 1942. stavila između prozorskih stakala, što je bio znak za susjedu da je Ružica odvedena (u logor Feričanci, gdje je umrla). Susjeda je djevojčicu prevezla vlakom u Zagreb Ružičinoj sestri Dragici Škulj-Jureković. 
Općine o potrebi lociranja židovske djece koja su ostala bez roditelja, a koja su $u$ ilegali kod udomitelja. Obavijestio je predsjedništvo da je i Ministarstvo socijalne politike pokrenulo sličnu akciju, u kojoj je lociralo oko 32.000 djece. Glesinger je pretpostavljao da među njima ima i dosta židovske djece. Naveo je da je situacija ustanovljavanja identiteta naročito teška kod jako male djece, koja ne znaju svoje pravo ime, a ponekad ga ne znaju ni udomitelji. Neka od te djece nisu se željela rastaviti od udomitelja: Glesinger je naveo primjer Đakova, gdje je židovski gostioničar, višestruko odlikovan invalid Prvog svjetskog rata (što ga je spasilo od progona), spasio troje djece iz đakovačkog logora i smjestio veći broj židovske djece kod nežidovskih obitelji, koje stanuju u okolici đakovačkoga mlina. Glesinger je predložio da ode u Đakovo i izvidi stvar. ${ }^{63}$ U monografiji Tome Šalića, Židovi u Vinkovcima i okolici, autor je naveo primjer Samuela Lea Grünwalda i Isidora Perere, koji su u siječnju 1942. iz logora Đakovo kamionom dovezli 58 djece u Vinkovce, koje su smjestili kod židovskih obitelji. Prema svjedočenju Samuela Lea Grünwalda o sudbini te djece, ona su početkom svibnja iste godine oduzeta udomiteljskim obiteljima te iz Vinkovaca prevezena u Osijek. Prema njegovom svjedočenju Šalić navodi da nije poznato što se dalje događalo s njima: sigurno je da je preživjela djevojčica Sarina Brodski. Šalić na drugom mjestu navodi da su ta djeca u svibnju iste godine prevezena vlakom u Osijek i raspoređena po židovskim obiteljima. Goldstein pak tvrdi da je većina djece u svibnju 1942. zajedno sa udomiteljima bila odvedena u logor i stradala. Uz ovu akciju navodi ime Samuela Lea Grünwalda, kao i da je industrijalac Emil Bačoka, vlasnik mlina u Vinkovcima dao Židovskoj opcini Vinkovci na raspolaganje kamion i vozača zbog prevoženja židovske djece iz logora Đakovo u Vinkovce. Čini se, prema dostupnim informacijama, da se ne radi o istom slučaju vezanom za Đakovo, koji navodi dr. Lavoslav Glesinger. ${ }^{64}$

Koliko je bilo djece po udomiteljskim obiteljima i koliko ih je zabilježeno u Općini, nema preciznih podataka. O kojem je broju preživjele djece koja su bila na skrbi u Općini riječ, djelomično se vidi iz korespondencije socijalnog odbora i Drage Rosenberga u vezi s izvješćem o broju preživjelih te o njihovu

63 JIM, arhiv ŽOZ, sign. K.63-1-1/1-148 od 2. studenog 1945. Nažalost, ni o ovom slučaju nema dovoljno podataka za njegovu potpunu rekonstrukciju.

ŠALIĆ 2002: 130-131, 433. GOLDSTEIN: Rukopis židovskog biografskog leksikona: Samuel Leo Grünwald (Babina Greda, 1920.), krojač. Od 1930. živio je s obitelji u Vinkovcima. Bio je jedan od predstavnika Židovske općine u Vinkovcima, koji su sudjelovali u dobavljanju pomoći u hrani i drugim potrepštinama zatočenicima u logoru u Đakovu, organizirajući sve poslove oko nabave hrane i dostave u logor. Uspio je uz odobrenje ustaške logorske uprave iz logora izdvojiti 57 djece, koju je smjestio kod židovskih obitelji u Vinkovcima kako bi bila spašena. Međutim, većina je djece u svibnju 1942., zajedno s udomiteljima, odvedena u logor te je stradala. Uhapšen u svibnju 1942. i odveden u Jasenovac, odakle je prebačen u Staru Gradišku i ponovno vraćen u Jasenovac. Uspio je pobjeći iz logora u veljači 1943. te je stupio u NOV. Bio je borac u 5. i 12. krajiškoj brigadi. Poslije rata bio je u službi u JNA u Zaječaru, Kragujevcu i Beogradu, gdje je ostao živjeti. 
stanju, radi slanja pomoći izvana. U izvješću se naročito ističe pitanje preživjele djece. Rosenberg moli za pomoć Joint, Svjetski židovski kongres (WJC) i druge židovske organizacije oko financiranja i uzdržavanja djece. Budući da Joint nije bio u mogućnosti izravno dostavljati pomoć, ŽBOZ neposredno pristupa Jointu u Bukureštu, gdje su se odvijali pregovori o neophodnoj financijskoj i humanitarnoj pomoći. Joint se potom uključuje u slanje pomoći slanjem tekstilne robe i hrane za židovske socijalne ustanove, kao i za ugrožene pripadnike zajednice. Općina je u izvješću, pisanom za tu svrhu, navela da ima oko 1.000 članova, od toga oko 100 djece. Općina izbacuje 1.000 tanjura (ručak/večera), smješta 60 staraca, 100 repatriraca, a preko 500 članova ovisno je o njezinoj pomoći. Dokument koji ilustrira stanje najesen 1945. jest telegram od 12. listopada 1945., koji ŽBOZ šalje međunarodnim židovskim organizacijama. Od 1.300 članova, u Općini ima oko 250 djece. Kuhinja dnevno izdaje 800 ručkova i Općina treba 800.000 dinara mjesečno za potporu i hranu, a hitno joj treba i rublje, odjeća i obuća te novac. ${ }^{65}$

\section{Potraga za preživjelima}

Židovska bogoštovna općina od svibnja 1945. bavi se i potragom za preživjelim članovima židovskih zajednica jer joj mnogi preživjeli članovi općine u zemlji i izvan nje šalju upite o svojim članovima obitelji ili prijateljima, čija im je sudbina nepoznata. Preživjeli isto tako Općini daju podatke i obavijesti o ubijenima, ponekad s točnim mjestom, vremenom ili načinom smrti. Kako bi stekla bolji uvid u svoje predratno članstvo, Općina poziva sve Židove, bez obzira na to jesu li pokršteni ili ne, da se prijave kod općine radi registracije, jer svakodnevno stižu upiti, kojima se rodbina raspituje za pojedince da li su isti $u$ životu ${ }^{66}$ Priče preživjelih i načini na koje su se spašavali ponekad su nevjerojatni. Često se dokumenti koji se nalaze u arhivu ŽOZ-a ne podudaraju sa stvarnim sudbinama, zato što autori nemaju sva saznanja o spašavanjima, niti su svi podaci u trenutku pisanja dokumenata došli od njih.

Iz korespondencije Općine s Judom/Leom Levijem iz Fort Ontaria, koji traga za svojom obitelji, doznajemo da je Dina Büchler (rođ. u travnju 1940.) s majkom odvedena u logor kod Loborgrada u lipnju 1941. U logoru se teško razboljela i krajem prosinca 1941. ili u siječnju 1942. Dina je, zahvaljujući logorskom čuvaru, spašena u dobi od 19 ili 20 mjeseci. Prema njezinu svjedočanstvu, danom kasnije, njezina joj je majka oko vrata stavila podatke o obitelji i rođacima. Logorski ju je

65 JIM, arhiv ŽOZ, sign. K.63(73)-1-1A/1; JIM, arhiv ŽOZ, sign. K-63-1-1/1-148 i drugi dokumenti bez signature i reg. br., uglavnom u kut. 63; JIM, arhiv ŽOZ, sign. K-62-5-1/1-230; JIM, arhiv ŽOZ, sign. K67-1-1/1 od 12. listopada 1945.

66 JIM, arhiv ŽOZ, sign. K.63(73)-1I-1/1 nepoznatog datuma iz 1945. U naslovu se Općina naziva Židovska općina, umjesto uobičajenog naziva Židovska bogoštovna općina. 
čuvar predao ŽBOZ-u, koja ju je predala majčinoj rođakinji Blanki Ziezer Forst. Potonja ju je pred odlazak u partizane predala prijateljici. Ona je, kao i rođakinja, preživjela rat, 1948. s rođakinjom emigrirala u Izrael te je njezino svjedočanstvo postalo poznato i može se vidjeti u Jad Vašemu, zajedno s ceduljicom, koju joj je majka objesila oko vrata. ${ }^{67}$

Općini je pisala i rodbina nadrabina Miroslava Šaloma Freibergera, kojoj nije bila poznata sudbina rabina i njegove obitelji. Iz Mandatne Palestine pisao je Cvi Freiberger, a iz SAD-a sestra Hilda Singer, tražeći informacije i nadajući se ponovnom susretu s njim. Dr. Branko Grossman iz Jeruzalema u lipnju 1945. pita o rođacima i prijateljima obitelji Hirschsohn iz Čakovca i Goldberger iz Križevaca. Za obitelj Hirschsohn (Ladislav, Rezika i dijete Ruben) iz Čakovca pita se iz Mandatne Palestine preko Delasema i u kolovozu 1945. Bela Frank iz Novog Sada u prosincu je pisao Općini, tražeći informaciju o palestinskom listu, u kojem su objavljeni podaci o njegovu sinu Ivanu (netko mu je u matičnoj općini rekao da je netko u Zagrebu u jednom palestinskom listu pronašao popis spašene djece, na kojem se nalazi i Ivan). Ivan je sada dvadesetogodišnjak, a on o njemu već godinu i pol ništa nije čuo. Bela Frank od Općine je dobio informacije o sinu, koji je preživio. Fogel (nepoznatog imena), rođ. Levi, od Općine je dobila informaciju da su u logor odvedeni i ubijeni njezini suprug, dvojica sinova i kći. ${ }^{68}$

U molbama i upitima doznajemo i o nekim sudbinama izbjeglica iz Njemačke, recimo Gizele i Ljud. (vjerojatno Ljudevita) Fürstenthala. Doznajemo da je on deportiran, a Gizela je preživjela u Zagrebu, no ništa više od toga. U arhivu se nalazi i potvrda da je dr. Ivan Gavrin stradao, dok njegova supruga Mira i djeca primaju pomoć od Općine. Dr. Dezider Julius, njegova obitelj i sin, koji su se iz partizana vratili u Zagreb, preko Općine šalju poziv da se rodbina javi dr. Juliusu na Rebro. ${ }^{69}$

Brojni su ovakvi dopisi, pozivi i obavijesti sačuvani u arhivu ŽOZ-a za 1945. Na dio potražnica članova obitelji, koje su oni upućivali Općini, njezino je vodstvo na temelju iskaza svjedoka i svoje evidencije izdavalo potvrde o njihovoj vjerojatnoj sudbini, međutim bilo je i odgovora da za mnoge pojedince nije bilo

67 JIM, arhiv ŽOZ, sign. K.63(73)1-1A/1.

68 JIM, arhiv ŽOZ, sign. K.63-1-1/1-19 (pismo Hilde Singer); JIM, arhiv ŽOZ, sign. K.63-11/1-235 (o obiteljima Hirschsohn i Goldberger) od 27. lipnja 1945. i JIM, arhiv ŽOZ, sign. K 63-2-1/1-16 iz kolovoza iste godine; JIM, arhiv ŽOZ, sign. K.63-1-1/1-19 (Bela Frank traži sina Ivana).

69 JIM, arhiv ŽOZ, sign. K.63-3-2/1-99 (obitelj Gavrin: svjedoci potvrđuju da je 1941. odveden u Jasenovac, a početkom je 1942. poginuo. Identificiraju ga kao dr. Ivana Schwarza-Gavrina); JIM, arhiv ŽOZ, K.63-2-1/1-97 (dr. Dezider Julius) i brojni drugi dopisi, često bez signature i reg. br. Više o Dezideru Juliusu i njegovim sinovima, Đuki i Stevi, vidi u autobiografiji Steve Juliusa: JULIUS 2005. 
moguće utvrditi u koji su logor odvedeni ili o njima nije bilo nikakvog podatka ili traga. ${ }^{70}$

\section{Vođenje matičnih knjiga}

Židovske vjeroispovijedne općine u neposrednom poraću nastavljaju voditi matične knjige, sve do proglašenja Zakona o državnim matičnim knjigama u travnju 1946..$^{71}$ Nakon završetka rata (čini se od 8. srpnja 1945. do 14. travnja 1946.) matične knjige vodi nadkantor Bernard Grüner $(1888 \text {. - 1955.) })^{72}$, a potom u Zagreb dolazi nadrabin dr. Hinko Urbach $(1872 \text {. - 1960. })^{73}$, koji preuzima njihovo vođenje. U siječnju 1949. sve su matične knjige predane u gradske matične urede, a u međuvremenu je nadrabin već bio emigrirao u Izrael. Iz tog je vremena

70 JIM, arhiv ŽOZ, sign. K.63(73)-1-1a/1, razni datumi iz 1945. U najvećem broju ovakvih dopisa pisalo je: ...osoba je odvedena u Loborgrad, a odande je premještena u Njemačku. Budući da se nitko živ iz te grupe nije vratio, to postoji vjerojatnost da više nije na životu ili ...kako su isti bez traga nestali iz Zagreba u doba kada su Židovi iz Zagreba odvađani u logore, postoji vjerojatnost da su gore navedena lica odvedena u jedan koncentracioni logor...

71 JIM, arhiv ŽOZ, razna mjesta. Zakon o državnim matičnim knjigama od 1. travnja 1946., Službeni list FNRJ, br. 29, 9. IV. 1946. Prema tom Zakonu, sve su se matične knjige morale predati državnim matičarima pri mjesnim i gradskim, odnosno rajonskim narodnim odborima. Zakon o izmjenama i dopunama Zakona o državnim matičnim knjigama objavljen je u Službenom listu FNRJ, br. 4, 12. I. 1949.

72 GOLDSTEIN: Rukopis Židovskog biografskog leksikona. Rođen u Poljskoj. Osnovnu i trogodišnju ekonomsku školu te ješivu završio u Budimpešti, a u Satu Mare/Szatmaru (sjeverozapadna Rumunjska) stječe svjedodžbu ortodoksnog rabina. Godine 1913. postaje nadkantor u Nitri (Slovačka), u Prvom svjetskom ratu mobiliziran i rat završava u činu kapetana. Od 1918. nadkantor središnje židovske općine u Budimpešti, od 1923. nadkantor u Szekesfehervaru, a od 1929. do smrti nadkantor u Zagrebu. Prvih dana nakon uspostave NDH uhićen s drugih četrdesetak uglednih i imućnih zagrebačkih Židova, čime ih se nastojalo zastrašiti i tako natjerati na prikupljanje kontribucije; ubrzo su svi pušteni. Iako i kasnije zatvaran i proganjan, za vrijeme NDH jedini židovski vjerski službenik koji je preživio rat u Zagrebu i u drugim dijelovima NDH pod ustaškom kontrolom, angažiran u mnogim poslovima općine, u pomoći zatočenicima u logorima, spasio svitke Tore iz sinagoge 1941. Od svibnja 1943. vodi službe Božje u zagrebačkom hramu. U braku s Johanom r. Izsak imao sina Theodora i kćer Editu (1922.), koja je 1942. odvedena u Auschwitz.

73 GOLDSTEIN: Rukopis Židovskog biografskog leksikona. Rođen u Moravskoj. Završio heder, osnovnu židovsku školu, a zatim ješivu, petogodišnji tečaj, u Bratislavi, u kojoj radi kao odgajatelj (do 1898.). Odlazi u Budimpeštu i završava srednju školu (1891.) te nastavlja višu rabinsku školu. Paralelno upisuje Filozofski fakultet u struci usporedne filozofije semitskih jezika, gdje 1904. doktorira. Kao rabin djeluje u Tuzli (1906. - 1911.), Zemunu (1911. - 1928.), a kao nadrabin u Sarajevu (1928. - 1946.). Predaje na Teološkom zavodu, koji je 1938. otvoren u Sarajevu. Cionist. Ljeti 1941. uspijeva pobjeći u Italiju, a potkraj 1943. u Švicarsku. Vraća se u Sarajevo 1945., u kojem je sva aškenaska populacija gotovo nestala. Godine 1946. premješten je u Zagreb, gdje djeluje dvije godine. Nakon osnutka države Izrael neko vrijeme radi na popisu kandidata za useljenje. Zajedno s ostalim iseljenicima odlazi u Izrael, noseći osamdesetak svitaka Tore, spašenih na tlu Jugoslavije. 
vrlo intenzivna korespondencija preživjelih članova s Nadrabinatom, u čijoj je nadležnosti vođenje matičnih knjiga, i to oko upisa u matice rođenih, vjenčanih i umrlih, odnosno pri traženju slobodnih listova (potrebnih za sklapanja braka).

Kod upisa u matične knjige umrlih, odnosno izdavanja smrtovnica, na primjeru dokumenata iz arhiva ŽOZ-a vidi se složena problematika upisa u službene matice umrlih osoba, osobito za one pojedince za koje nikada nije došao službeni dokument ili potvrda o smrti, na temelju kojih je moguće provesti upis u matične knjige umrlih. Iz tog se razloga u arhivu nalazi niz dokumenata, u kojima svjedoci navode mjesto i vrijeme smrti, ako im je ono bilo poznato. Nadrabinat, odnosno Općina neko je vrijeme izdavala potvrde, koje su vrijedile kao smrtovnice. Primjer je dopis Općine Rudolfu Weinbergeru, u kojem ga Općina informira da mu ne može izdati smrtovnicu za brata jer nikada nisu dobili službenu obavijest ni o jednom smrtnom slučaju iz Jasenovca, na temelju koje bi mogli provesti upis u matične knjige umrlih. ${ }^{74}$ Iz drugih dopisa Općine navedeno je da je potvrda Općine vrijedila kao smrtovnica, a u drugom dopisu iz istog fonda vidljivo je da su se potvrde izdavale i na temelju kartoteke $S k r b$ za logore, gdje su se unosila javljanja logoraša. ${ }^{75}$

Zanimljivo je, u kontekstu proučavanja židovske povijesti, pratiti nekoliko slučajeva provođenja postupka razvoda braka. Iz nekoliko djelomično sačuvanih slučajeva razvoda braka, osim same procedure razvoda (koja je gotovo u potpunosti sačuvana samo u jednom slučaju), može se proučavati i krizu u obitelji, kao posljedicu, odnosno uzrokovanu razdobljem Šoa ${ }^{76}$ Ovom prilikom iznijet ću tek nekoliko crtica, sačuvanih u arhivima Općine, s obzirom na to da, u kontekstu ovog šireg pristupa problematici, pokušavam rekonstruirati hrvatsku epizodu krize židovske obitelji u razdoblju Šoa i neposrednog poraća. Pristupajući ovoj tematici fenomenološki, u oči upada kombinacija jugoslavenskog poslijeratnog i rabinskog prava. U slučaju razvoda Gustava i Mire Gavrin, Nadrabinat dobiva pravomoćnu presudu Okružnog narodnog suda za Grad Zagreb o razvodu tog braka. Presudom je Gustavu Gavrinu iz Zagreba dopušteno predavanje raspusnog lista (get) Miri Gavrin (rođ. Schneller), koja živi u Tel Avivu, a njoj je naloženo da primi raspusno pismo, činom kojim bi brak, što su ga gornje stranke sklopile 10. listopada 1937., po židovskom obredu bio razvrgnut. Brakorazvodna parnica vodila se preko skrbnika određenog za Miru Gavrin (Teodor Durman), s obzirom na to da poštanski promet $\mathrm{s}$ Tel Avivom tada nije funkcionirao, a i ona je sama željela razvrgnuti brak. Budući da u braku nije bilo djece, nije bilo ni pitanja oko njihova uzdržavanja. ${ }^{77}$ I slučaj razvoda braka Stjepana Pećija i Piroške Sidon (koja

\footnotetext{
74 JIM, arhiv ŽOZ, sign. K.63-3-3/1-47.

75 JIM, arhiv ŽOZ, sign. K.63-3-3/1-46.

76 O ovoj tematici vidi OFER i WEITZMAN 1999: 9-24.

77 JIM, arhiv ŽOZ, sign. K.60-5-1/1-149.
} 
se tada nalazi u Rimu) odvija se preko posrednika, Jedidije ben Derviša. Spis o razvodu sadrži tekst punomoći za posrednika na hebrejskom, da se njemu uruči get od strane rimskog nadrabinata. ${ }^{78}$

Niz je ovakvih slučajeva razvoda preko posrednika, s obzirom na to da supružnik/ca sada živi negdje drugdje. Brakovi se često i razvode zbog napuštanja, a niti preljub nije rijedak razlog. Među dokumentacijom postoji i Svjedodžba o neuspjelim pokušajima pomirenja, koju izdaje Nadrabinat te njome uredovno potvrđuje da je u bračnom sporu nastojao u tri navrata najkrepčim opomenama pomiriti navedene. Ova svjedodžba izdaje se na njihovu molbu, kako bi mogli u smislu Građanskog zakona povesti postupak pred redovitim građanskim sudom prema paragrafu 133-134 o. g. Kao što se vidi iz dokumentacije, Nadrabinat je potom izvješće o primopredaji raspusnog pisma između obiju strana u brakorazvodnom postupku slao Kotarskom sudu te je time njihov brak, sklopljen po židovskom obredu, konačno razvrgnut. Kotarski sud molio je Nadrabinat i za pojašnjenje daljnjeg postupka u svrhu upisa klauzule o razvodu braka u Maticu vjenčanih nadrabinata u Zagrebu. ${ }^{79}$

Pitanje razvoda brakova u poslijeratnim godinama bilo je vrlo problematično, iz razloga što se vjerski propisi o brakovima nisu podudarali s građanskim zakonima o braku, koji su doneseni 1946., odnosno s formom sklapanja ili razvoda braka, što je provodila narodna vlast na oslobođenim područjima. Pitanje pravilnog razvoda braka, odnosno njegova nedostatka za sobom vuče ozbiljne posljedice za ženu u židovskom pravu jer, u nedostatku geta (dokumenta o razvodu, odnosno u ovim dokumentima raspusnog pisma), svaka njezina buduća zajednica definira se kao preljub, a potomci takve zajednice imaju osjetljiv položaj unutar židovskog prava. ${ }^{80}$ Takav je bio slučaj Nikolaja Zarnika, koji je tražio posredovanje od ŽBOZ-a kako bi dobio papir za razvod braka od Nade Jelinek/Zarnik/Lustig. Naime, on se s Nadom po zamjeniku vjenčao u Zagrebu 25. kolovoza 1943., dok je ona bila u logoru na Rabu, međutim ona je nakon oslobođenja Raba prebačena u Bari i ondje se udala 25. ožujka 1945. u židovskoj općini za Lustiga (u dokumentu se ne navodi njegovo osobno ime). On je u posredovanje razvoda uključio Općinu jer međunarodni poštanski promet nije bio u funkciji. Okolnosti u kojima se ona mogla ponovno udati nisu jasne, no njemu je kao temelj za razvod bio dovoljan njezin novi vjenčani ugovor. ${ }^{81}$

\footnotetext{
78 JIM, arhiv ŽOZ, sign. K.60-5-1/1-130 do 132.

79 JIM, arhiv ŽOZ, sign. K.60-5-1/1-138; JIM, arhiv ŽOZ, sign. K.60-5-1/1-145; JIM, arhiv ŽOZ, sign. K.60-5-1/1-46 od 6. srpnja 1945.; JIM, arhiv ŽOZ, sign. K.60-5-1/1-152; JIM, arhiv ŽOZ, sign K.60-5-1/1-153 i drugi.

80 Ako je brak sklopljen prema židovskom pravu, onda se na takav način mora i razvesti, bez obzira na eventualno postojanje institucije građanskog razvoda braka jer je takav razvod za židovsko pravo nevažeći.

81 JIM, arhiv ŽOZ, sign. K.63-3-3/1-157 od 14. rujna 1945.
} 


\section{Pitanje komunalne imovine, pomoć članovima kod traženja povrata osobne} imovine, društvena djelatnost Židovske bogoštovne općine u Zagrebu

Od ljeta i ujesen 1945. Općina se počinje baviti pitanjem naslijeđene imovine od pojedinaca ili tvrtki, koji su svoje nasljedstvo ostavili Općini. U arhivu ŽOZ-a sačuvana je korespondencija s bankama. Općina 7. srpnja piše Gradskoj štedionici o štednoj knjižici, koju je naslijedila na šifru A. G. Istog dana piše i Hrvatskoj kreditnoj banci d. d. iz Zagreba o šifriranoj uložnoj knjižici Julio. Prvoj hrvatskoj štedionici piše o njihovim dvjema uložnicama, koje im je ostavio R. D. Isto tako, Općina piše i Hrvatskoj udruženoj banci d. d. o pitanju nasljedstva od iste osobe (gdje se poziva na javnobilježnički akt 8/1939 od 7. studenog 1939., kojim je R. D. dio imetka ostavio ŽBO-u u Zagrebu) te moli za obavijest o pitanju uložnica koje bi trebale biti kod njih. Istog mjeseca piše i Trgovačkoj banci d. d. u Zagrebu o uložnicama koje postoje u općinskoj, ali ne i u bankovnoj evidenciji. ${ }^{82}$ Osim bankama, Općina u vezi s nasljedstvom i komunalnom imovinom, ovaj put nekretninama, piše i PTT-u, Kotarskom narodnom sudu za grad Zagreb, Gradskoj upravi narodnih dobara (GUND) i drugim institucijama. Tako možemo pratiti slučaj povrata općinske zgrade u Amruševoj 8, u koju se smjestio PTT. Zgrada je zaključkom Kotarskog narodnog suda za grad Zagreb od 16. srpnja 1945. R. 233/45, vraćena u vlasništvo ŽBOZ-a. Nakon toga Općina iznajmljuje zgradu PTTu. Dana 25. rujna Općina šalje dopis GUND-u o naslijeđenoj imovini, koju joj je ostavio Robert Deutsch, kao i obavijesti stanarima koji su se nalazili u stanovima, koji su bili u njegovu vlasništvu, o novoj visini stanarine. Općina poziva i druge pravne i fizičke osobe da riješe svoj najamni odnos s njima kao vlasnikom (npr. Državno trgovačko poduzeće Narodni magazin u Amruševoj 4). ${ }^{83}$ Iz dostupne arhivske građe nije jasno je li Općina uspjela dobiti svoje nasljedstvo. Svakako se zna da je sve općinske i zgrade židovskih organizacija, koje je ona osnovala, relativno skoro ponovno izgubila uslijed valova nacionalizacija i drugih imovinskih zakona, uredbi i propisa.

Zagrebačka općina bavi se i sudbinom ratom uništenih općina, njihovim svetim predmetima i sinagogama, grobljima i drugom imovinom. Odmah u ljeto 1945. Općina je tražila izviješće o stanju po općinama u svojem širem okruženju: sačuvana su izviješća iz Nove Gradiške, Kutine, Lipika, Pakraca, Daruvara i Koprivnice.U

82 JIM, arhiv ŽOZ, sign. K.63-1-1/1-216 od 7. srpnja 1945., sign. K.63-1-1/1-318-6 od 7. srpnja 1945., sign. 63-3-3/1-1 od 27. kolovoza 1945., sign. K.63-3-2/1-152 od 12. srpnja (Trgovačka banka d. d.).

83 JIM, arhiv ŽOZ, sign. K.63-3-2/1, razno, npr. dopisi od 4. i 8. kolovoza, 4. rujna i 26. rujna 1945. (PTT); JIM, arhiv ŽOZ, sign. K.63-1-1/1-218 od 21. rujna i K.63-1-1/1-217 od 25. rujna 1945. Vidi i sign. K.63-3-3/1-142-149, rujan 1945. i sign. K63-2-1/1-51; JIM, arhiv ŽOZ, sign K.63(73)-1-1/1 od 10. prosinca 1945. (DTP NaMa). 
kojima se navodi broj članova koji su se vratili u navedene gradove i njihovu okolicu, u kakvom su stanju bili hramovi, što se dogodilo s ritualnim predmetima te se daju procjene štete po tečaju dinara iz 1939. godine. ${ }^{84}$ Iz dokumenata se čini se da je zagrebačka Općina poticala Židove na teritoriju predratnih općina, gdje one nisu (još) obnovljene, na osnivanje odborâ, koji bi predstavljali pojedine općine, pobrinuli se za hram i groblje te drugu imovinu općine, popisali nepokrštene Židove te se brinuli za siromašne i djecu bez roditelja. Takvi su se odbori očito osnivali i kako bi podnosili molbe Kotarskim narodnim odborima da se nekretnine u vlasništvu predratnih općina ponovno upišu u gruntovnicu u vlasništvo židovskih općina. To se može zaključiti iz dopisa zagrebačke općine Ivici Pollaku iz Bjelovara (nasljednici tvornice Pollak iz Bjelovara), u kojem se predlaže osnivanje odbora u Bjelovaru, uz primjedbu da su takve odbore već formirale i neke manje općine u Hrvatskoj. ${ }^{85}$ Vrlo brzo zagrebačka općina počinje pružati i pravnu pomoć hrvatskim Židovima u pitanjima povrata nepokretne imovine, pomoć kod lociranja njihovih pokretnina, sklonjenih za vrijeme rata, te drugu pravnu pomoć i savjete.

Općina je u lipnju 1945., na traženje Zemaljske komisije za utvrđivanje zločina okupatora i njihovih pomagača Hrvatske, provodila registraciju Židova u Zagrebu, kao što je to bio slučaj sa svim općinama koje su obnovile svoj rad. ${ }^{86}$ Rezultat su bili popisi preživjelih članova općine, a neke su općine na svojim popisima posebno navodile tko se vratio na područje njihove općine, a prije rata bio je član neke druge općine, kao i za one za koje postoji informacija da su na putu kući. ${ }^{87}$

84 JIM, arhiv ŽOZ: sačuvana su izvješća iz Nove Gradiške, Kutine, Lipika i Pakraca (bez reg. br. i sign.), Daruvara (K.63-3-2/1-151) i Koprivnice (K.63-3-2/1-10).

85 JIM, arhiv ŽOZ, sign. K.63(73)1II-1A/1, dopis od 26. rujna 1945.; JIM, arhiv ŽOZ, sign. K.63-3-2/1-151 (Daruvar i okolica); JIM, arhiv ŽOZ, sign. K.63-3-2/1-10 od 21. rujna 1945. (Koprivnica i okolica); JIM, arhiv ŽOZ, sign. K.63, F3, K2, bez datuma (Kutina i okolica); JIM, arhiv ŽOZ, bez sign., kut. 63, F3 K.2 (Lipik i okolica); JIM, arhiv ŽOZ, bez sign., kut. 63, F3 K.2; potpisan Julio Wachsler (Nova Gradiška i okolica); JIM, arhiv ŽOZ, bez sign., kut. 63, F3 K.2. (Pakrac i okolica). Iz izvješća se vidi da je većina predratnog članstva ovih općina ubijena u Šoa te da je većina komunalne imovine uništena: većina je sinagoga oštećena, uništena ili spaljena; neizvjesna je sudbina Tore i njezina nakita, a različita je i sudbina židovskih groblja. JIM, arhiv ŽOZ, bez reg. br., sign. K.63-3-1/1-154. HR-HDA-ZKRZ GUZ 2235/V-1945.

87 JIM, arhiv ŽOZ: Spiskovi preživjelih po abecedi za cijelu Jugoslaviju. Hrvatske su općine u ovom popisu Čakovec s dvama sumarnim popisima, neposredno nakon rata, s nekim nepodudarnostima (K.64-1-1/1 od 19. kolovoza i 25. kolovoza 1945.) te popisom od 10. veljače 1946. (K.64-11/1-6), koji sadrži Židove koji su u Čakovcu, pokrštene Židove u Čakovcu, one iz okolice na području ovoga ŽBO-a te one koji su preživjeli, ali se nisu vratili u Čakovec, kao i one koji su na putu kući; Dubrovnik od 11. ožujka 1945. (K.64-1-1-/1-8 i K.64-1-1-/1-9); Ilok od 17. kolovoza 1945. (K.64-1-1-/1-11); Karlovac (K.64-1-1-/1-12); Osijek (K.64-1-1-/1-26) s 181 preživjelim na popisu; Rijeka/Fiume od 7. prosinca 1945. (K.64-1-1-/1 i K. 64-1-1-/1-32); Sušak (K.64-1-1-/1 i K.64-1-1-/1-41); Našice (K.64-1-1-/1-34), 5 osoba; Split (K.64-1-1-/1-39) sa 171 preživjelim i posebnim popisom od 12 žena i djece arijevaca udanih za Židove; Varaždin (K.64-1-1-/-46), 26 osoba; Vinkovci (K.64-1-1-/1-47), 12 osoba. Za usporedbu, podaci o većim općinama: Novi Sad ima 809, Sarajevo 851 čl. na popisu za grad i okolicu, Subotica 1050. Zagreba ovdje nema. 
S ovim je popisima u vezi i dopis od 22. listopada 1945., koji zagrebačka općina upućuje Zemaljskoj komisiji za utvrđivanje ratnih zločina, gdje se Komisiju izvještava da je obećano sabiranje podataka o nestalim Židovima u punom radu, no s obzirom na obimnost, bit će gotovo tek krajem idućeg mjeseca, $\mathrm{s}$ tim da se, $\mathrm{u}$ ovom slučaju, radi o popisima Židova ubijenih u $\breve{S}_{0} a{ }^{88} \mathrm{U}$ kontekstu procesa protiv ratnih zločinaca, Općina je bila uključena i u potragu za svjedocima, pa je tako u listopadu 1945. objavila oglas da se pri Javnom tužiteljstvu u Sremskoj Mitrovici vodi kazneni postupak protiv Andrije Kovačevića iz Zemuna zbog kaznenog djela protiv naroda i države. Optuženi je, kao njemački vojnik SS-a, bio stražar u koncentracijskom logoru kod Lublina od 1942. do proljeća 1944., a nakon toga je premješten u Varšavu kao stražar za geto te kao stražar u koncentracijskom logoru Kaunfering kod Münchena. U oglasu se traži da se jave eventualni svjedoci ${ }^{89} \mathrm{Na}-$ ime, od 1942. Volksdeutscheri iz jugoistočne Europe često su se slali u čuvarsku službu raznih logora u okupiranoj Poljskoj, pa je, na primjer, među čuvarima u Auschwitzu bilo između $11 \%$ i 15\% prijeratnih državljana Kraljevine Jugoslavije. ${ }^{90}$

Općina je na zahtjev izdavala i zahvale pojedincima, naročito onima koji su radili za ustaške vlasti, a koji su na različite načine pomagali u spašavanju Židova. Te su zahvale vrlo često bile potrebne takvim pojedincima kako bi dokazali svoju nevinost i opravdali razlog zbog kojeg su radili za njemačke ili ustaške vlasti. Tako u arhivu ŽOZ-a postoji i nekoliko dokumenta, u kojima Općina zahvaljuje pojedincima za pomoć, koju su tijekom rata pružili Židovima. Općina šalje i pismo zahvale Branku Milakoviću, povjereniku aškenaske sarajevske jevrejske općine za vrijeme NDH, koji nakon završetka rata postaje predstojnik Kotarskog narodnog suda u Sarajevu. Drugi je dokument zahvala Općine Zvonku Finku, ravnatelju tvornice Gorica d. d. u Zagrebu, na pomoći u opskrbljivanju raznih logora, staračkih domova i menze, koje je davao bez doznaka i znanja ustaških vlasti. Dopis je napisan na zahtjev Zvonka Finka. U trećem primjeru Općina potvrđuje da je pri transportu Židova u logore za vrijeme NDH viša glavna sestra Crvenog križa Dragica Habazin ljudima činila velike usluge, a s njom je uvijek surađivala bolničarka Danica Šauli. Općina šalje i zahvalu časnim sestrama za sačuvane pokretnine pojedinca. ${ }^{91}$ Domobranski časnik

88 JIM, arhiv ŽOZ, razne signature (od K.64-1-1/1-1 do K.64-1-1/1-47); JIM, fond ŽOZ, sign. K.63-3-3/1-162: dopis od 22. listopada 1945.

Historical-Sociological Profile of the Auschwitz SS, 271-287, naročito tablicu na str. 281, gdje se navode podaci o 74 jugoslavenskih državljana od ukupno 670 za 1942. (11\%), 118 od ukupno 796 za 1943. (14,8\%), 129 od ukupno 945 za 1944. (13,7\%) i 92 od ukupno 721 za 1945. (12,8\%).

91 JIM, arhiv ŽOZ, sign. K.63(73)-1-1/1 od 6. srpnja 1945. (zahvala Branku Milakoviću); JIM, arhiv ŽOZ, sign. K.63-1-1/1-18 od 15. studenog 1945. (Zvonko Fink); JIM, arhiv ŽOZ, sign. K.63-1-1/1-264 od 3. prosinca 1945. (sestra Crvenog križa Danica Habazin, inače i jedna od ključnih suradnica Dijane Budisavljević). 
S., koji čeka amnestiju, preporučuje pomoć za udovicu s troje djece, koju je očuvao kroz rat. ${ }^{92} \mathrm{U}$ dopisu Općini Sabina Majzl moli da joj se podijeli besplatna hrana u pučkoj kuhinji jer je potpuno bez sredstava. Postavljena je za povjerenika u trgovini Jakoba Schäffera, ali do dana kada se obratila Općini još nije dobila plaću. Na dopisu je napisano do daljnj, što bi značilo da je ona zaista dobivala pomoć u Općini. ${ }^{93}$

Vrlo malo ili gotovo nikako dokumentima nije pokriven odnos između povratnika iz koncentracijskih logora, ratnog zarobljeništva, partizana ili internacije i onih koji su rat preživjeli u Zagrebu. ${ }^{94}$

\section{Konstituiranje Židovske bogoštovne općine u Zagrebu u rujnu 1945.}

Tijekom ljeta 1945. počinje rad na konstituiranju općine. U srpnju je ŽBOZ pozivao sve Židove da se prijave u Općinu do 10. kolovoza. Pripadnici mogu postati samo osobe židovske vjere, koji imaju prebivalište u gradu Zagrebu. Istovremeno Općina prima i već spomenuta očitovanja o povratku u židovsku vjeru. Najavljuju se izbori za općinski odbor Židovske bogoštovne općine u Zagrebu; tijekom kolovoza pripremaju se izbori i članstvo poziva na skupštinu. Na skupštini je izabran kandidacijski odbor, koji raspisuje izbore za 23. rujna, do kada je predana samo jedna kandidacijska lista, ona koju je predložio Kandidacijski odbor. Zato se izbori ne provode, već se 23. rujna saziva Kandidacijski odbor, koji konstatira da su sve izborne predradnje propisno obavljene te se konstituirajuća sjednica Židovske bogoštovne općine u Zagrebu saziva za 24. rujna 1945. Izabrano je vijeće od 25 članova s njihovim zamjenicima te članovi Nadzornog odbora. ${ }^{95}$ Do 1946. predsjednik je i dalje bio Robert Glücksthal, kada na njegovo mjesto dolazi dr. Arpad Hahn. ${ }^{96}$

\footnotetext{
JIM, arhiv ŽOZ, bez sign. i reg. br., kut. 63, od 26. rujna 1945.

93 JIM, arhiv ŽOZ, sign. K.63(73)1II-1A/1 od 28. lipnja 1945.

94 HR-HDA-306 ZKRZ - GUZ 2235/2-45 (arhivski fond Zemaljske komisije za utvrđivanje zločina okupatora i njihovih pomagača Hrvatske). Radi se o pokušaju rekonstrukcije rada Odbora za podavanja. U ovom se nizu dokumenata naziru kompleksni odnosi između članova židovske zajednice i određena doza sumnje, posebice između onih koji su ostali u Zagrebu i onih koji su odvedeni ili bili prisiljeni bježati. Očigledna je sumnja na Hinka Manna, člana Odbora za podavanja, kojeg su određeni članovi zajednice u jednom izbjegličkom logoru u Italiji sumnjičili da se okoristio radom u Odboru. Jedna od osoba, koja je primila poziv da se javi istražitelju Zemaljske komisije za istraživanje ratnih zločina (ZKRZ), bio je Robert Glücksthal, koji se pod prijetnjom posljedica za slučaj neopravdanog izostanka morao pojaviti pred istražnim referentom, dr. Ernstom. Teško je iz ovoga izvući zaključak o okolnostima poziva, s obzirom na to da nije postojao standardiziran način obraćanja u dopisima, pa se stilovi, od dokumenta do dokumenta, jako razlikuju.
}

95 JIM, arhiv ŽOZ, sign. K.63(73)-1I-1/1.

96 GOLDSTEIN: Rukopis Židovskog biografskog leksikona. Diplomirao na Medicinskom fakultetu, specijalizirao se za internu medicinu. Ovlaštenje za obavljanje liječničkog zvanja dobio 


\section{Religijski život u ŽBOZ-u nakon rata}

U arhivu zagrebačke židovske općine pronašla sam jako malo tragova o vjerskom životu zajednice, iako je poznato da ga je bilo, ali u smanjenom opsegu, do 1948. - 1949. Vjenčanja su se do 1946. odvijala prema židovskom zakonu, no nakon što je uvedena institucija građanskog braka takvo je vjenčanje ovisilo o izboru mladenaca. Više nije bilo košer dućana, pa se nije moglo doći do košer namirnica, osim kroz materijalnu pomoć, koju su pružale međunarodne židovske organizacije. Tore, molitvenici i ritualni predmeti uglavnom su, kao što se može vidjeti iz izvješća židovskih zajednica o stanju na koje su naišli iza rata, bili ukradeni ili uništeni, pa su i u tom pravcu židovske zajednice dobivale pomoć od međunarodnih židovskih organizacija.

S obzirom na to da je ustaška vlast na početku razdoblja svoje vlasti srušila sinagogu u Praškoj, preživjeli nisu imali ni prostor u kojem bi proslavili velike židovske blagdane, kada se i u sekularnim zajednicama većina njihovih članova okuplja u sinagogama. Budući da Općina nije imala molitveni prostor, iznajmljivala je javne zagrebačke prostore za različite blagdane. Povodom organiziranja proslave Hanuke, 2. i 3. prosinca 1945., od Narodnog kazališta posuđuje kabele. Od 1945. ili 1946. za Velike blagdane (Roš hašana i Jom kipur) Općina je unajmljivala dvoranu Hrvatskoga glazbenog zavoda. Iz Općine su se članstvu slale obavijesti o dodjeljivanju alijot (javno čitanje Tore u sinagogi/molitvenom prostoru) na Toru za Roš Hašana i Jom Kipur. Nadrabin Hinko Urbach organizirao je i uvoz etrogim ${ }^{97}$, koji su Židovima neophodni za blagdan Sukot. ${ }^{98}$

\section{Alijá bet ${ }^{99}$}

U prosincu 1944. izaslanici alijá bet prvi put dolaze u Jugoslaviju kako bi obnovili prijeratne veze s lokalnom židovskom zajednicom i provjerili odnos novog

1934. Istaknuti član NK Makabi iz Zagreba, a nakon igračke karijere dužnosnik u klubu. Prije Drugog svjetskog rata u Zagrebu, Smičiklasova 18, imao vlastitu liječničku ordinaciju. Ljeti 1941., zajedno sa skupinom židovskih liječnika te suprugom Dragom i sinom Mirom (1931.), poslan u BiH, u Mostar, kako bi se liječio endemski sifilis. U logoru u Kuparima, pa onome na Rabu. Nakon kapitulacije Italije u rujnu 1943. priključuje se NOB-u zajedno s obitelji. Poslije rata redovni profesor MF-a u Zagrebu te dekan od 1960. do 1963. Predstojnik Interne klinike Kliničkog bolničkog centra 1951. - 1967. Predsjednik ŽO-a u Zagrebu od 1946. do 1951.

Etrog (mn. etrogim) je vrsta citrusa, koja se koristi kao jedna od četiriju biljaka u ritualima za blagdan Sukot (Blagdan sjenica, jedan od triju hodočasnih blagdana u židovstvu, koji se obilježava u jesen, najčešće u listopadu).

98 JIM, arhiv ŽOZ, sign. K.63(73)-1-1/1 od 29. studenog 1945. (Roš hašana, 1945.); JIM, arhiv ŽOZ, sign. K.71-1a-3/1 i 3/2 (Veliki blagdani 1945./1946. - 1947.; potvrdu HGZ-a 1947. potpisuju Ivo Steiner i Ivo Tijardović); JIM, arhiv ŽOZ, sign. K.71-1a-4 (alijot na Toru za Roš hašana i Jom kipur 1946. - 1947.): JIM, arhiv ŽOZ, sign. K.71-1a-1/1 do 1/4 (uvoz etroga). 
režima prema cionizmu. S obzirom na geografski položaj i obalu punu zaklonjenih luka, njegova je ideja bila podizanje baze za isplovljavanje u jugoslavenskoj luci, odakle bi brodovi isplovljavali za Erec Israel. ${ }^{100} \mathrm{U}$ razdoblju od kraja 1944. do proglašenja Države Izrael 15. svibnja 1948. (ne)suradnja židovskih organizacija, involviranih u alijá bet, i jugoslavenskih vlasti proći će kroz nekoliko epizoda uspona i padova. U tom će razdoblju Jugoslavija, uz povremene prekide, propuštati židovske izbjeglice preko svog teritorija, no svojim židovskim građanima neće dozvoljavati iseljavanje u Izrael. U kontekstu teme ovog članka spomenut ću tragove, koje o alijá bet postoje u hrvatskim arhivima. Očigledno je da su postojale i konkretne akcije na terenu jer se u arhivu Židovske (vjeroispovijedne) općine u Zagrebu nalazi općinska potvrda da su Cvi Vjernik (rođen 21. rujna 1919. u Rišonu) i Naĥama Vjernik (rođena 21. rujna 1919. u Aku) u procesu repatrijacije u prolazu u Zagrebu te su privremeno smješteni u općinskom prihvatilištu na Trgu kralja Tomislava 4/II, dok ne pribave potrebne papire kako bi se mogli priključiti skupini repatriraca; do tog trenutka bave se prihvaćanjem repatriraca koji prolaze kroz Zagreb. U studenom Općina ovlašćuje Cvija Vjernika da uime Općine posreduje kod Društva Crvenog križa i kod Glavnog štaba za repatrijaciju u Ljubljani u predmetu transporta Židova - prolaznika, koji se vraćaju iz koncentracijskih logora, a idu svojim kućama. U arhivu nalazimo i potvrdu da je Općina Cviju Vjerniku predala razne živežne namirnice (suhu hranu) radi opskrbe repatriraca, koji iz Zagreba preko Ljubljane putuju prema svojim odredištima, te molbu da se spomenutome ne dogodi nikakva neprilika. S obzirom na njihova imena, kao

99 Faza ilegalne imigracije Židova u Palestinu, poznata pod nazivom alijá bet, relativno je slabo poznata u hrvatskoj historiografiji. Zato se ovaj odlomak gotovo isključivo oslanja na rad Menahema Šelaĥa, Ha-Kešer ha-Jugoslavi: Jugoslavia ve- 'alija bet 1938-1948 (ŠELAĤ 1994), kao i na arhivski fond HR-HDA-1522: Zemaljska komisija za repatrijaciju Hrvatske, gdje se može naslutiti dio prelazaka Židova različitih nacionalnosti preko Jugoslavije u Italiju i potvrditi tzv. repatrijacija Palestinaca, o čemu će u ovom poglavlju biti više riječi.

100 Alijá bet: ('עלייה בהפלה) naziva se još i ha-apala (העליה), uzdizanje. U prvoj fazi, od 1934. do 1942., radilo se na izvlačenju Židova pred nacističkim progonima i uništenjem. Do kasne 1938. u organizaciji nije sudjelovalo političko vodstvo Sohnuta, s obzirom na to da je ono polagalo nade u ubrzano cjelovito rješenje palestinskog pitanja, osobito u svjetlu židovske potpore za vrijeme arapskog ustanka i Peelova izvješća, no nakon što Britanci napuštaju ideju osnivanja židovske države, političko vodstvo mijenja svoj stav prema Britancima. U toj prvoj fazi na ilegalnom useljavanju radi nekoliko neovisnih organizacija i pojedinaca, najviše He-haluc (organizacija židovske omladine, čiji je cilj bio obučavanje njezinih članova vještinama potrebnima za naseljavanje Erec Israela; s vremenom postaje krovna organizacija pionirskoga pokreta cionističke židovske omladine), kao i cionisti revizionisti: אף על פי כן (Af-al-pi-hen operacije, nazvane tako prema jednom od brodova kojim su se prevozili useljenici). Unatoč tome što vodstvo jišuva nije sudjelovalo, u ovoj su fazi aktivisti Hagana uzimali udio u organiziranju ilegalnih useljavanja. Do početka Drugog svjetskog rata oko 24.000 osoba došlo je u Erec Israel kao ilegalni imigranti. Od tog broja, za dolazak oko 18.000 njih odgovorni su revizionisti. Neki od preostalih 6.000 došli su i na komercijalnim osnovama. 
i neobično podudarne datume rođenja te mjesta rođenja u Mandatnoj Palestini, ali najviše radi rute, kojima se koristila alijá bet na putu prema Italiji, može se, s priličnom dozom sigurnosti, zaključiti da su Cvi i Naĥama Vjernik operativci jedne od organizacija koja organizira alijá bet preko jugoslavenskog teritorija. ${ }^{101}$ Ovaj se proces može pratiti i u arhivskom fondu Zemaljske komisije za repatrijaciju Hrvatske, bilo da se radi o repatrijaciji Mađara, Rumunja ili Poljaka ili o tzv. repatrijaciji Palestinaca. ${ }^{102}$

\section{Zaključak}

Židovska zajednica u Hrvatskoj gotovo je uništena u razdoblju Šoa. Ubijeno je između 70\% i 80\% hrvatskih Židova, a njihova je imovina opljačkana ili uništena. Najveći broj prijeratnih židovskih općina nakon Drugog svjetskog rata nije obnovljen, a židovska se društva pri općinama, kao i ona druga, zbog promjene društvenog sustava nakon rata nisu smjela obnoviti; opljačkana je i uništena i njihova imovina, kao i groblja i ostala materijalna i nematerijalna kultura.

Međutim, unatoč vrlo nepovoljnim uvjetima, činjenica da je zagrebačka općina (Židovska bogoštovna općina) djelovala kroz cijelo razdoblje NDH, i to ne u obliku predratnih općina u ovom dijelu Europe, nego sa sasvim novim, nametnutim zadacima, kao što su briga za deportirane Židove po koncentracijskim logorima, kao i za one malobrojne koji su ostali na teritoriju NDH zaštićeni po raznim osnovama, $i$ to vlastitim, odnosno sredstvima prikupljenima od uglavnom međunarodnih židovskih organizacija pomogla je brzoj organizaciji pomoći preživjelima, koji se od svibnja 1945. vraćaju u Zagreb i Hrvatsku. Vodstvo Općine, postavljeno u svibnju 1943., nakon zadnjih velikih deportacija iz Zagreba i dalje je imalo kontakte s međunarodnim židovskim organizacijama i bilo je naviknuto na rad u nenormalnim uvjetima. Nakon oslobođenja vrlo su se brzo provodile organizacije, na jako sličan način kao za vrijeme rata. Prva je briga Općine sada bila smjestiti i nahraniti povratnike, a zatim im pomoći u potrazi za preživjelim članovima obitelji, kao i za pokretnom i nepokretnom imovinom. Vodstvo zagrebačke Židovske općine, uz brigu za vlastitu imovinu, brinulo se i za imovinu općina u sjevernom dijelu Hrvatske.

$\overline{101}$ JIM, arhiv ŽOZ, sign. K.63-3-3/1-113; JIM, arhiv ŽOZ, sign. K.63-3-3/1-122 od 9. studenog 1945.; JIM, arhiv ŽOZ, sign. K.63-3-3/1-121 od 9. prosinca; JIM, arhiv ŽOZ, sign. K.63-33/1-120 od 14. prosinca.

102 HR-HDA-1522: Zemaljska komisija za repatrijaciju Hrvatske, opis fonda. Fond sadrži spise koji se odnose na praćenje i upućivanje repatriraca preko jugoslavenske granice u pripadne zemlje preko pograničnih stanica, a uključene su kategorije ratnih zarobljenika, interniraca, izbjeglica i žrtava fašističkog terora različitih narodnosti: Rumunji, Bugari, Mađari, Palestinci, Talijani, Poljaci, Česi, Nijemci i drugi. 
Ono što nije vidljivo iz samog arhiva Općine, iako se može zaključiti sondiranjem arhiva u potrazi za točno određenim detaljima, jest i suradnja Općine s izaslanicima alijá bet (kodno ime za ilegalnu alijá, odnosno ilegalno useljavanje u Erec Israel, koja traje od 1934. do 1948., kao židovski odgovor na britanske kvote), baš kao što se to događalo na razini Saveza.

Analizirajući način organizacije i područja odgovornosti, može se zaključiti da je Općina funkcionirala i kao svojevrsna inačica SJVOJ-a na lokalnoj razini, dajući savjetodavnu i logističku potporu tek obnovljenim općinama na teritoriju Hrvatske i Slovenije, što će nastaviti raditi i u sljedećem razdoblju, koje izlazi izvan okvira ovog članka, naročito za vrijeme alijá (iseljavanja) u Izrael.

\section{Bibliografija}

\section{Kratice}

JIM: Jevrejski istorijski muzej (Beograd)

JVOZ: Jevrejska vjeroispovijedna općina u Zagrebu

SJVOJ: Savez jevrejskih veroispovednih opština Jugoslavije

ŽBOZ: Židovska bogoštovna općina u Zagrebu

ŽOZ: Židovska općina Zagreb

\section{Neobjavljeni izvori}

Arhiv Jugoslavije: Prezidijum Narodne skupštine FNRJ; Pretsedništvo vlade FNRJ; Ministarstvo pravosuđa Vlade FNRJ; Komitet za socijalno staranje Vlade FNRJ.

Državni arhiv u Zagrebu: HR-DAZG-943 Sudbeni stol u Zagrebu; HR-DAZG-252 Trgovinska komora u Zagrebu.

Hrvatski državni arhiv: Ravnateljstvo ustaškog redarstva. Židovski odsjek (HR-HDA-252); Zemaljska komisija za repatrijaciju Zagreb, 1945-1947. (HR HDA 1522); Odjeljenje zaštite naroda za Hrvatsku (OZNA) (HR HDA 1491); Zemaljska uprava narodnih dobara (ZUND) (HR HDA 313); Zemaljska komisija za utvrđivanje zločina okupatora i njihovih pomagača (ZKRZ) (HR-HDA-306).

Jevrejski istorijski muzej u Beogradu (JIM): Arhiv ŽOZ, tzv. Pererin arhiv, Spiskovi preživelih Jevreja u Jugoslaviji, Autonomni odbor za pomoć Beograd, SJVO, Beograd 1946.

\section{Objavljeni izvori}

KEVO, Mario (ur.). 2009. Veze Međunarodnog odbora Crvenog križa i Nezavisne Države Hrvatske: dokumenti. Knjiga 1. Zagreb: Hrvatski institut za povijest, Podružnica za povijest Slavonije, Srijema i Baranje Slavonski Brod, Hrvatski državni arhiv Zagreb, Javna ustanova Spomen-područje Jasenovac. 


\section{Periodika}

Narodne novine (1941.)

\section{Literatura}

BANKIER, David (ed.). 2005. The Jews Are Coming Back: The Return of the Jews to Their Countries of Origin after WWII. Jerusalem: Yad Vashem and Berghahn Books.

BRANDL, Naida Mihal. 2015. Židovski identiteti u Hrvatskoj iza Drugog svjetskog rata. U Nacionalne manjine u Hrvatskoj i Hrvati kao manjina-europski izazovi: zbornik s međunarodnog znanstveno-stručnog skupa Annales Pilar 2012., ur. Ljiljana Dobrovšak, Ivana Žebec Šilj, 167-194. Zagreb: Institut društvenih znanosti „Ivo Pilar“.

FRIEDLANDER, Saul. 2009. Nazi Germany and the Jews, 1939-1945: Abridged Edition. London: Harper Collins.

GITMAN, Esther. 2012. Kad hrabrost prevlada. Spašavanje i preživljavanje Židova u Nezavisnoj Državi Hrvatskoj 1941-1945. Zagreb: Kršćanska sadašnjost.

GOLDSTEIN, Ivo. 2002. Istraživanje židovskih žrtava: razmatranja o Zagrebu i Hrvatskoj. U Dijalog povjesničara - istoričara 5, ur. Hans-Georg Fleck, Igor Graovac, 445-463. Zagreb: Zaklada Friedrich Naumann.

GOLDSTEIN, Ivo. 2004. Genocid nad Židovima u Nezavisnoj državi Hrvatskoj. Povijest u nastavi 2/1 (3): 40-50.

GOLDSTEIN, Ivo. 2004. Restoring Jewish Life in Communist Yugoslavia, 1945-1967. East European Jewish Affairs 34/1: 58-71.

GOLDSTEIN, Ivo, Slavko GOLDSTEIN. 2001. Holokaust u Zagrebu. Zagreb: Novi Liber, Židovska općina Zagreb.

GRAHEK RAVANČIĆ, Martina. 2013. Narod će im suditi. Zemaljska komisija za utvrđivanje zločina okupatora i njihovih pomagača za Zagreb 1944-1947. Zagreb: Hrvatski institut za povijest.

GRBEŠIĆ, Grgo. 2003. Prijelazi Židova u Katoličku crkvu u Đakovačkoj i srijemskoj biskupiji od 1941. do 1945. Croatica Christiana Periodica XXVII/52: 155-169.

GUTMAN, Yisrael, Michael BERENBAUM (ur.). 1998. Anatomy of the Auschwitz Death Camp. Bloomington: Indiana University Press.

JELIĆ-BUTIĆ, Fikreta. 1977. Ustaše i NDH. Zagreb: Sveučilišna naklada Liber, Školska knjiga.

KARAKAŠ OBRADOV, Marica. 2013. Prisilne migracije židovskog stanovništva na području Nezavisne Države Hrvatske. Croatica Christiana Periodica XXXVII/72: 153-187.

KARAKAŠ OBRADOV, Marica. 2014. Novi mozaici nacija u „Novim poredcima“. Migracije stanovništva na hrvatskom području tijekom Drugoga svjetskog rata i poraća. Zagreb: Hrvatski institut za povijest.

KERKKÄNEN, Ari. 2001. Yugoslav Jewry: Aspects of Post-World War II and Post-Yugoslav Developments. Helsinki: Studia Orientalia.

KISIĆ KOLANOVIĆ, Nada. 1998. Podržavljenje imovine Židova u NDH. Časopis za suvremenu povijest 30/3: 429-453.

LEVI-DALE, David (ur.). 1970. Spomenica Saveza jevrejskih opština Jugoslavije, 19191969. Beograd: SJOJ-Srboštampa. 
MATICKA, Marijan. 1992. Zakonski propisi o vlasničkim odnosima u Jugoslaviji (19441948). Radovi Zavoda za hrvatsku povijest 25: 123-148.

OFER, Dalia, Lenore WEITZMAN. 1999. The Role of Gender in Holocaust Research. Yalkut Moreshet 67: 9-24.

PAVER, Josipa Bosiljka. 1989. O arhivskoj građi ZAVNOH-a u Arhivu Hrvatske. Arhivski vjesnik 32/33: 87-93.

PERERA, David. 1970. Neki statistički podaci o Jevrejima u Jugoslaviji u periodu od 1938. do 1965. godine. U Jevrejski almanah 1968-1970, 135-147. Beograd: Savez jevrejskih opština Jugoslavije

ROMANO, Jaša. 1980. Jevreji Jugoslavije 1941-1945, Žrtve genocida i učesnici narodnooslobodilačkog rata. Beograd: Jevrejski Istorijski Muzej Saveza jevrejskih opština Jugoslavije.

ROSEN, Mark I. 2010. Mission, Meaning and Money: How the Joint Distribution Committee Became a Fundraising Innovator. Bloomington: Universe.

SOBOLEVSKI, Mihael. 1998. Zagrebačka židovska općina od 1941. do 1945. godine. U Dva stoljeća povijesti i kulture Židova u Zagrebu i Hrvatskoj, ur. Ognjen Kraus, 28-46. Zagreb: Židovska općina Zagreb.

STRČIĆ, Petar. 1998. Pljačka zlata (1.065,339 kg) zagrebačkih Židova (svibanj-listopad 1941). U Dva stoljeća povijesti i kulture Židova u Zagrebu i Hrvatskoj, ur. Ognjen Kraus, 47-58. Zagreb: Židovska općina Zagreb.

ŠALIĆ, Tomo. 2002. Židovi u Vinkovcima i okolici. Osijek: Židovska općina Osijek.

ŠELAĤ, Menaĥem. 1990. Toldot ha-Šoa - Jugoslavia, Jerušalajim: Jad Vašem.

ŠELAĤ, Menaĥem. 1994. Ha-Kešer ha-Jugoslavi: Jugoslavia ve-'alija bet 1938-1948. Tel Aviv: Am oved.

TOMAŠEVIĆ, Jozo. 2010. Rat i revolucija u Jugoslaviji: okupacija i kolaboracija 19411945. Zagreb: EPH, Novi Liber.

ZUCKERMAN, Boško. 2010. Političke prilike tijekom ustrojstva NDH i psihologija Holokausta Židova u Bosni i Hercegovini 1941. godine. Prilozi Instituta za istoriju u Sarajevu 39: 51-86.

ŽIVAKOVIĆ KERŽE, Zlata. 2006. Od židovskog naselja u Tenji do sabirnog logora. Scrinia Slavonica 6: 497-514.

ŽIVAKOVIĆ KERŽE, Zlata. 2007. Podržavljenje imovine Židova u Osijeku u NDH. Časopis za suvremenu povijest 39/1: 97-116.

\section{Biografije}

JULIUS, Stevo. 2005. Ni crven ni mrtav. Zagreb: Durieux.

\section{Neobjavljeni rukopisi}

BRATANIĆ, Mateo. 2009. Hrvatski zbjegovi u Egipat 1943-1946. Neobjavljena doktorska disertacija. Zadar: Sveučilište u Zadru.

GOLDSTEIN, Ivo (gl. ur.). Židovski biografski leksikon. Rukopis. Zagreb: Hrvatski leksikografski zavod Miroslav Krleža. 


\section{Activities of the Jewish Religious Community in Zagreb in 1945 and 1946}

The Jewish community in Croatia was almost destroyed in the period of the Shoah. Between 70 and 80 percent of Croatian Jews were killed and their property was looted or destroyed. The largest number of pre-war Jewish communities after World War II as well as Jewish societies was not renewed. Their property was also looted and destroyed. Similar was the case with cemeteries and other tangible and intangible cultural heritage.

However, despite the very adverse conditions, the fact that the Jewish religious community functioned for the entire war period, not in the form of pre-war communities in this part of Europe, but with a completely new, imposed functions: care for deported Jews in concentration camps, and for the few who remained in the territory of the ISC protected on various grounds, and to do it with its own funds (raised from mainly international Jewish organizations), helped prompt the organization to help the survivors, which started to return to Zagreb and Croatia after the liberation. The leadership of the Community since May of 1943 had contacts with international Jewish organizations and was accustomed to working in abnormal conditions so they very quickly organized themselves, in much the same way as during the war.

This article analyzes the activities of the Zagreb Jewish community in the immediate post-war period, from the summer of 1945 until 1946 based on the archives of the community from the Jewish Historical Museum in Belgrade. Its activities consist of the administrative assistance for baptized Jews to return to Judaism, the care of a nursing home, of helping survivors in the form of accommodation, food and health care, searching for the hidden children, as well as providing assistance to members and other Croatian Jews in search for their family members as well as for their movable and immovable property. The community was also taking care of registrars books, as well as cataloguing assets destroyed in the war and was involved in the revival of the religious life.

Keywords: Jewish community, Zagreb, Shoah, World War II, post-war period

Ključne riječi: Židovska zajednica, Zagreb, Šoa, Drugi svjetski rat, poratno razdoblje

Naida Mihal Brandl Filozofski fakultet Sveučilišta u Zagrebu HR-10000 Zagreb, Ivana Lučića 3 mbrandl@ffzg.hr 


\section{FILOZOFSKI FAKULTET SVEUČILIŠTA U ZAGREBU \\ ZAVOD ZA HRVATSKU POVIJEST \\ INSTITUTE OF CROATIAN HISTORY \\ INSTITUT FÜR KROATISCHE GESCHICHTE}
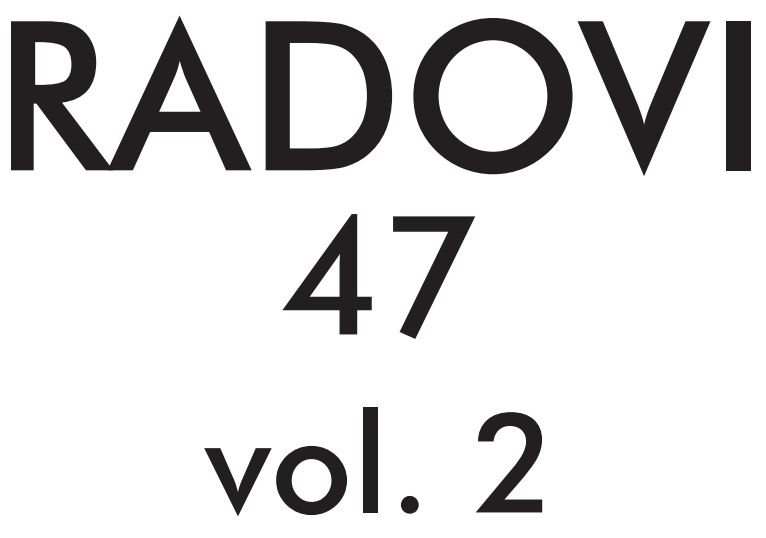

ZAVOD ZA HRVATSKU POVIJEST

FILOZOFSKOGA FAKULTETA SVEUČILIŠTA U ZAGREBU

FF press

ZAGREB 2015. 


\title{
RADOVI ZAVODA ZA HRVATSKU POVIJEST FILOZOFSKOGA FAKULTETA SVEUČILIŠTA U ZAGREBU
}

\author{
Knjiga 47, vol. 2
}

\author{
Izdavač / Publisher \\ Zavod za hrvatsku povijest \\ Filozofskoga fakulteta Sveučilišta u Zagrebu \\ FF-press \\ Za izdavača / For Publisher \\ Vlatko Previšić \\ Glavni urednik / Editor-in-Chief \\ Hrvoje Gračanin \\ Izvršna urednica / Executive Editor \\ Inga Vilogorac Brčić \\ Uredništvo / Editorial Board
}

Bruna Kuntić-Makvić (stara povijest/ancient history), Zrinka Nikolić Jakus (srednji vijek/ medieval history), Hrvoje Petrić (rani novi vijek/early modern history), Željko Holjevac (moderna povijest/modern history), Tvrtko Jakovina (suvremena povijest/contemporary history),

Silvija Pisk (mikrohistorija i zavičajna povijest/microhistory and local history),

Zrinka Blažević (teorija i metodologija povijesti/theory and methodology of history)

Međunarodno uredničko vijeće / International Editorial Council

Denis Alimov (Sankt Peterburg), Živko Andrijašević (Nikšić), Csaba Békés (Budapest), Rajko Bratož (Ljubljana), Snježana Buzov (Columbus, Ohio), Svetlozar Eldarov (Sofija), Toni Filiposki (Skopje), Aleksandar Fotić (Beograd), Vladan Gavrilović (Novi Sad), Alojz Ivanišević (Wien),

Egidio Ivetić (Padova), Husnija Kamberović (Sarajevo), Karl Kaser (Graz),

Irina Ognyanova (Sofija), Géza Pálffy (Budapest), Ioan-Aurel Pop (Cluj),

Nade Proeva (Skopje), Alexios Savvides (Kalamata), Vlada Stanković (Beograd), Ludwig Steindorff (Kiel), Peter Štih (Ljubljana)

Izvršna urednica za tuzemnu i inozemnu razmjenu / Executive Editor for Publications Exchange Kristina Milković

Tajnik uredništva / Editorial Board Assistant
Dejan Zadro

Adresa uredništva/Editorial Board address

Zavod za hrvatsku povijest, Filozofski fakultet Zagreb, Ivana Lučića 3, HR-10 000, Zagreb

Tel. ++385 (0)1 6120 150, 6120 158, faks ++385 (0)1 6156879

Časopis izlazi jedanput godišnje / The Journal is published once a year

Časopis je u digitalnom obliku dostupan na / The Journal in digital form is accessible at Portal znanstvenih časopisa Republike Hrvatske „Hrčak“ http://hrcak.srce.hr/radovi-zhp

Financijska potpora za tisak časopisa / The Journal is published with the support by

Ministarstvo znanosti, obrazovanja i športa Republike Hrvatske

Časopis je indeksiran u sljedećim bazama / The Journal is indexed in the following databases:

Directory of Open Access Journals, EBSCO, SCOPUS, ERIH PLUS 
Naslovna stranica

Iva Mandić

Grafičko oblikovanje i računalni slog

Marko Maraković

Lektura

Samanta Paronić

Tisak

Web2tisak, Zagreb

Naklada

250 primjeraka

Časopis je u digitalnom obliku dostupan na Portalu znanstvenih časopisa Republike Hrvatske ,Hrčak“ http://hrcak.srce.hr/radovi-zhp

The Journal is accessible in digital form at the Hrcak - Portal of scientific journals of Croatia http://hrcak.srce.hr/radovi-zhp 


\section{RADOVI 47}

\section{vol. 2}

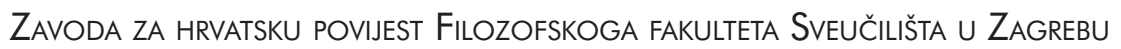

